\title{
Leguminosae em fragmentos de floresta estacional semidecidual, Araponga, MG: árvores e lianas
}

\author{
José Martins Fernandes ${ }^{1}$, Flávia Cristina Pinto Garcia ${ }^{1,3}$, Lívia Constancio de Siqueira ${ }^{1}$ e \\ Carolina Pellucci Barreto Marotta ${ }^{2}$
}

Recebido: 25.09.2008; aceito: 30.12 .2010

\begin{abstract}
Leguminosae in fragments of seasonal semideciduous forest, Araponga, MG: trees and lianas). A total of 26 species distributed in 12 genera and seven tribes were sampled in two fragments of seasonal forest during the period of one year. The subfamily Papilionoideae was the most represented with 11 species, five of which belong to genus Machaerium. The tribes Dalbergieae (10 spp.) and Ingeae (5 spp.) comprised 58\% of species, among them, Dalbergia nigra (Vell.) Allemão ex Benth. are included in the endangered species list, and Abarema obovata (Benth.) Barneby \& J.W. Grimes, whose distribution is limited to the State of Minas Gerais. The study presents analytical key, description and illustrations of species, flowering and fruiting times, as well as geographical distribution.
\end{abstract}

Key words: floristics, Leguminosae, Semideciduous Forest

RESUMO - (Leguminosae em fragmentos de floresta estacional semidecidual, Araponga, MG: árvores e lianas). Durante o período de um ano, foram amostradas em dois fragmentos de floresta estacional 26 espécies, distribuídas em 12 gêneros e sete tribos. A subfamília Papilionoideae foi a mais representada com 11 espécies, destas, cinco espécies são Machaerium. As tribos Dalbergieae (10 spp.) e Ingeae (5 spp.), reuniram 58\% das espécies, entre elas, Dalbergia nigra (Vell.) Allemão ex Benth. incluída na lista das espécies ameaçadas de extinção, e Abarema obovata (Benth.) Barneby \& J.W. Grimes, com distribuição restrita ao Estado de Minas Gerais. O trabalho apresenta chave analítica, descrições e ilustrações das espécies, período de floração e frutificação, além da distribuição geográfica.

Palavras-chave: Floresta Semidecidual, florística, Leguminosae

\section{Introdução}

Leguminosae Adans. com 36 tribos, 727 gêneros e cerca de 19.325 espécies, é considerada a terceira maior família de angiospermas com distribuição cosmopolita (Lewis et al. 2005). Em relação às subfamílias, recentes estudos filogenéticos baseados em dados moleculares indicaram Caesalpinioideae como parafilética, e Papilionoideae e Mimosoideae como monofiléticas (Wojciechowski et al. 2004). Ocupa desde os picos das serras montanhosas até o litoral arenoso, da floresta tropical úmida até desertos, ocorrendo até em ambientes aquáticos (Polhill 1981).

No Brasil ocorrem cerca de 210 gêneros e 2.694 espécies de Leguminosae, sendo a principal família no país (Forzza et al. 2010). Está presente nos diversos ecossistemas no Brasil, em especial na Floresta Atlântica, onde esta família possui elevada representatividade entre os elementos do estrato arbóreo (Lima et al. 2009).

Apresentam-se como ervas anuais ou perenes, eretas, prostradas difusas, trepadeiras, lianas, subarbustos, arbustos e árvores de pequeno, médio ou grande porte (Lewis 1987). A família é monofilética e apresenta as seguintes sinapomorfias: folhas compostas, alternas, com pulvinos, uma pétala adaxial diferenciada, ovário monocarpelar e fruto do tipo legume (Chappill 1995), com as variações: bacóide, nucóide e samaróide. No entanto, Leguminosae possui outros tipos de frutos como folículo, criptolomento, craspédio, lomento, criptossâmara, sâmara, drupa e sacelo (Barroso et al. 1999).

1. Universidade Federal de Viçosa, Departamento de Biologia Vegetal, Programa de Pós-Graduação em Botânica, Av. P.H. Rolfs s.n., 36570-000 Viçosa, MG, Brasil

2. Universidade Federal de Viçosa, Departamento de Engenharia Florestal, Av. P.H. Rolfs s.n., 36570-000 Viçosa, MG, Brasil

3. Autora para correspondência: fcgarcia@ufv.br 
Os estudos taxonômicos realizados com Leguminosae em florestas estacionais semideciduais em Minas Gerais, mostraram a grande diversidade da família nesse tipo de vegetação (Bortoluzzi et al. 2003, 2004, Filardi et al. 2007, Lima et al. 2007). Em estudos florísticos do estrato arbóreo, Oliveira-Filho (2006) citou Leguminosae com uma das principais famílias em número de espécies para o estado. Saporetti-Júnior (2005) e Soares et al. (2006) em estudo fitossociológico do estrato arbóreo em áreas no município de Araponga, citaram a família como uma das principais na composição florística e na estrutura da vegetação.

Os fragmentos de Floresta Estacional Semidecidual estudados localizam-se no entorno do Parque Estadual da Serra do Brigadeiro (PESB), Estado de Minas Gerais, sob domínio da Floresta Atlântica, considerado como um dos "hotspots", devido à alta biodiversidade na região (Myers et al. 2000). Assim, o estudo teve como objetivos identificar as espécies arbóreas e lianas de Leguminosae ocorrentes em dois fragmentos florestais no município de Araponga, Minas Gerais, com a elaboração de chave analítica, descrições e ilustrações dos gêneros e táxons específicos e infra-específicos, período de floração, frutificação e distribuição geográfica.

\section{Material e métodos}

O levantamento florístico foi realizado em dois fragmentos florestais localizados entre os meridianos $42^{\circ} 32^{\prime} \mathrm{S}$ e $42^{\circ} 27^{\prime} \mathrm{W}$ e os paralelos $20^{\circ} 38^{\prime} \mathrm{W}$ e $20^{\circ} 43^{\prime} \mathrm{S}$ (figura 1), no município de Araponga, Zona da Mata, sudeste de Minas Gerais, no entorno do Parque Estadual da Serra do Brigadeiro. São áreas particulares, com cerca de 3 (Fragmento da Eva) e 5 (Fragmento da Lurdinha) hectares cada, e que sofreram, ao longo do tempo, a retirada de "madeira nobre".

A vegetação é caracterizada como Floresta Estacional Semidecidual (Veloso et al. 1991). O clima é do tipo $\mathrm{Cw}_{\mathrm{b}}$ a $\mathrm{Cw}_{\mathrm{a}}$ (mesotérmico); a precipitação anual varia de 1.200 a $1.800 \mathrm{~mm}$; o relevo é montanhoso com declividade variando de $20 \%$ a $45 \%$ nas encostas, com altitude média de 1.000 metros, e solo predominantemente Latossolo (Golfari 1975).

O material botânico foi coletado a partir de visitas mensais aos fragmentos entre agosto de 2005 e outubro de 2006. A amostragem consistiu da coleta de ramos férteis, realizada durante caminhadas pelo entorno e no interior dos fragmentos, sendo herborizado de acordo com técnicas tradicionais (Fidalgo \& Bononi

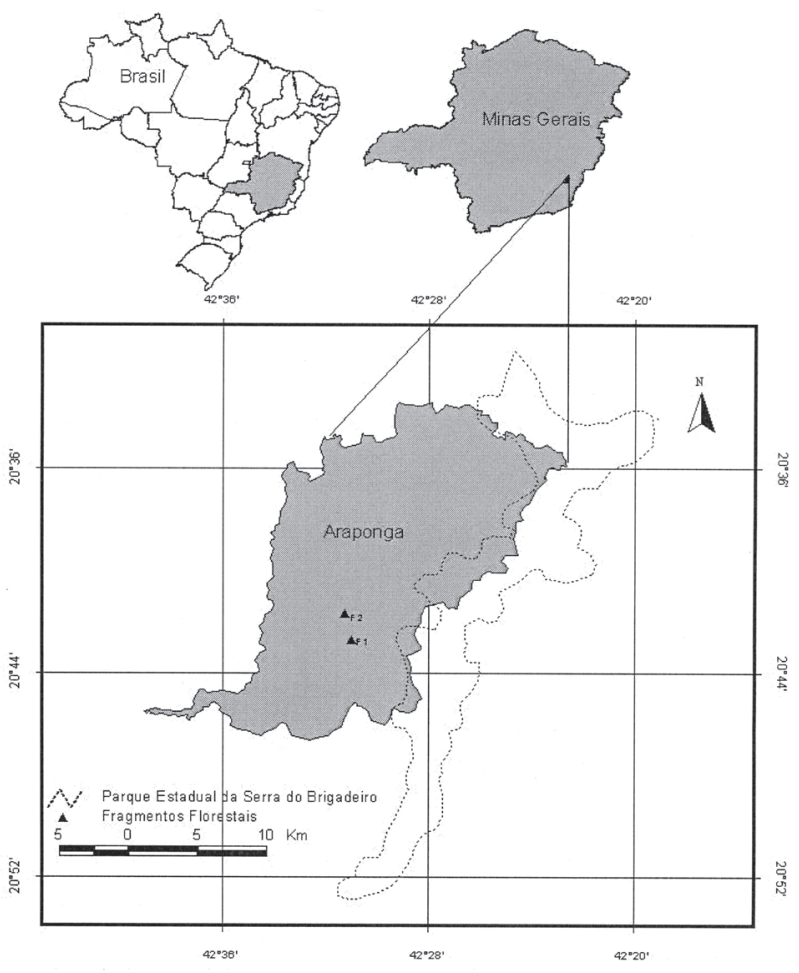

Figura 1. Localização dos fragmentos de floresta estacional semidecidual estudados no município de Araponga, Minas Gerais: $\mathrm{F} 1=$ Fragmento da Lurdinha e F2 = Fragmento da Eva.

Figure 1. Location of fragments of semideciduous forest surveyed in the municipality of Araponga, Minas Gerais: F1 = Fragment at Lurdinha's farm and F2 = Fragment at Eva's farm.

1989), registrado e depositado no acervo do Herbário VIC, do Departamento de Biologia Vegetal, da Universidade Federal de Viçosa.

O sistema de classificação adotado para família, subfamílias e gêneros está de acordo com Lewis et al. (2005), e a caracterização quanto ao hábito conforme Guedes-Bruni et al. (2002).

As descrições dos gêneros foram baseadas na literatura taxonômica, e dos táxons, com base no material coletado; para esta publicação foi selecionado o material mais representativo com flor e/ou fruto para cada espécie; são acompanhadas de ilustrações, comentários sobre período de floração e frutificação, obtidas através de observações dos indivíduos, além de distribuição geográfica e habitat dos táxons. A terminologia adotada nas descrições morfológicas foi baseada em Radford et al. (1974), complementada com termos específicos obtidos em revisões dos gêneros e, para os tipos de frutos, foi utilizada a classificação de Barroso et al. (1999).

As ilustrações dos caracteres diagnósticos das espécies foram realizadas a partir de estruturas desenvolvidas com o auxílio de uma câmara clara 
acoplada a estereomicroscópio Zeiss, utilizando-se material rehidratado e fixado em álcool $70 \%$.

\section{Resultados e Discussão}

O levantamento de Leguminosae arbóreas e lianas em fragmentos de floresta estacional semidecidual, em Araponga (MG), amostrou 26 espécies, incluídas em 12 gêneros e sete tribos. Número de espécies maior que o encontrado por Soares et al. (2006) que identificaram 11 espécies de Leguminosae em estudo florístico das espécies arbóreas em floresta estacional semidecidual montana em Araponga, entre elas, Cassia ferruginea Schrader ex DC., Inga cylindrica (Vell.) Mart., Inga sessilis (Vell.) Mart., Machaerium brasiliense Vogel e Swartzia pilulifera Benth., também foram amostras neste estudo.

Os gêneros mais representativos foram Machaerium Pers., com cinco espécies, Inga Mill., com quatro espécies, Dalbergia L., Piptadenia Benth. e Tachigali Aubl., com três espécies cada, enquanto os outros estão representados por duas ou uma espécie cada. Machaerium é um dos mais representativos em estudos florísticos (Meira Neto \& Martins 2002, Bortoluzzi et al. 2004, Rodrigues \& Garcia 2007), que segundo Rudd (1977), é considerado como um dos maiores gêneros lenhosos em florestas tropicais, com cerca de 130 espécies.

Papilionoideae com 11 espécies, foi à subfamília mais representada, seguida por Mimosoideae e Caesalpinioideae com nove e seis espécies, respectivamente. Rodrigues \& Garcia (2007) identificaram 12 espécies de Papilionoideae na Estação de Pesquisa, Treinamento e Educação Ambiental (EPTEA), Mata do Paraíso, Viçosa (MG), semelhante ao encontrado neste estudo.

As tribos mais expressivas nos fragmentos foram Dalbergieae, com 10 espécies, representada pelos gêneros Andira Lam. (1 sp.), Dalbergia L. (3 spp.), Hymenolobium Benth. (1 sp.) e Machaerium (5 spp.); Ingeae, com os gêneros Inga (4 spp.) e Abarema (1 sp.); Cassieae, com os gêneros Cassia L. (1 sp.) e Senna Mill. (2 spp.); Caesalpinieae e Mimoseae representadas por Tachigali (3 spp.) e Piptadenia (3 spp.), respectivamente; e com apenas uma espécie cada, as tribos Acacieae (Acacia Mill.) e Swartzieae (Swartzia Schreb.). O hábito arbóreo foi o mais representado com 19 espécies, enquanto que as lianas, totalizaram apenas seis espécies. No entanto, Machaerium acutifolium Vogel é encontrado nos fragmentos com as duas formas de hábitos.

Nos fragmentos foram amostrados Dalbergia nigra (Vell.) Allemão ex Benth., que está inserida na lista das espécies ameaçadas de extinção (Drummond et al. 2005), e Abarema obovata (Benth.) Barneby \& J.W. Grimes, com distribuição restrita ao Estado de Minas Gerais. Dados que demonstram a importância da conservação dos fragmentos florestais estudados que mantém grande diversidade de Leguminosae, contribuindo para a permanência de espécies raras e/ou com distribuição restrita ao Estado de Minas Gerais, no entorno do Parque Estadual da Serra do Brigadeiro.

Chave para identificação das espécies de Leguminosae em fragmentos florestais, Araponga (MG): árvores e lianas

1. Folhas pinadas

2. Folhas paripinadas

3. Nectários foliares presentes

4. Nectários foliares pateliformes, funiliformes ou cupuliformes; corola gamopétala, actinomorfa

5. Raque foliar cilíndrica; inflorescências espiciformes; corola até 4,3 mm compr. 9. Inga cylindrica

5. Raque foliar alada; inflorescências em racemos congestos; corola acima de $13 \mathrm{~mm}$ compr.

6. Folíolos (2)-3-5 pares; nectários foliares pateliformes ou funiliformes; frutos retos

7. Pecíolo cilíndrico; nectários foliares pateliformes, sésseis; cálice estriado longitudinalmente 12. Inga striata

7. Pecíolo alado; nectários foliares funiliformes, estipitados; cálice sem estrias 10. Inga platyptera 
6. Folíolos 6-7 pares; nectários foliares cupuliforme-compressos; frutos curvos

4. Nectários foliares fusiformes ou piriformes; corola dialipétala, zigomorfa ou assimétrica

11. Inga sessilis

8. Folíolos 2 pares; nectários foliares piriformes; corola zigomorfa

2. Senna macranthera var. nervosa

8. Folíolos 12-45 pares; nectários foliares fusiformes; corola assimétrica ...... 3. Senna multijuga

3. Nectários foliares ausentes

9. Folíolos até 2,8 cm compr.; 3 estaminódios presentes; fruto lomento drupáceo

9. Folíolos acima de $4 \mathrm{~cm}$ compr.; estaminódios ausentes; fruto criptossâmara

10. Folíolos 5-7 pares, denso-tomentosos na face abaxial

11. Indumento canescente; nervuras terciárias inconspícuas; estilete até $0,9 \mathrm{~mm}$ compr.

4. Tachigali friburgensis

11. Indumento áureo; nervuras terciárias conspícuas; estilete acima de $1,5 \mathrm{~mm}$ compr.

.. 6. Tachigali rugosa

10. Folíolos 14-16 pares, glabrescentes em ambas as faces

5. Tachigali paratyensis

2. Folhas imparipinadas

12. Estipelas presentes

13. Folíolos até 9

14. Corola presente; fruto drupa

16. Andira surinamensis

14. Corola ausente; fruto legume 26. Swartzia pilulifera

13. Folíolos acima de 29

12. Estipelas ausentes

15. Lianas ou arbustos escandentes

16. Plantas inermes

17. Ápice dos folíolos retuso a agudo; sâmara com núcleo seminífero central

18. Dalbergia frutescens var. frutescens

17. Ápice dos folíolos acuminado; sâmara com núcleo seminífero basal

24. Machaerium triste

16. Plantas armadas

18. Folíolos oblongos, até $1,9 \mathrm{~cm}$ compr.; sâmara geniculada ....25. Machaerium uncinatum

18. Folíolos elípticos a obovados, acima de 3,5 cm compr.; sâmara reta

15. Árvores

19. Região seminífera central

20. Estames 10; ovário glabro com margens ciliadas

19. Dalbergia nigra

20. Estames 9; ovário totalmente viloso

17. Dalbergia foliolosa

19. Região seminífera basal

21. Folíolos com ápice retuso

23. Machaerium nyctitans

21. Folíolos com ápice acuminado a agudo

22. Ramos armados; região seminífera rugosa

21. Machaerium acutifolium

22. Ramos inermes; região seminífera reticulada

22. Machaerium brasiliense

1. Folhas bipinadas

23. Árvores

24. Pinas 2-3 pares; foliólulos 2-5 pares por pina; legume circinado

7. Abarema obovata

24. Pinas 7-14 pares; foliólulos 27-44 pares por pina; legume reto

14. Piptadenia gonoacantha

23. Lianas

25. Nectários foliares cupuliformes; inflorescências capituliformes

25. Nectários foliares pateliformes; inflorescências espiciformes

26. Pinas 4 pares; foliólulos 2-5 pares por pina, vilosos

8. Acacia martiusiana

26. Pinas 11-17 pares; foliólulos 34-40 pares por pina, glabros

13. Piptadenia adiantoides

15. Piptadenia micracantha 
Subfamília Caesalpinioideae

1. Cassia ferruginea Schrader ex DC., Prodr. 2: 489. $1825 \equiv$ Bactyrilobium ferrugineum Schrader, Goett. Gel. Anz. 1(72): 713. 1821.

Figura $2 \mathrm{a}-\mathrm{b}$

Árvores 8-10 m alt.; ramos jovens tomentosos. Estípulas 1,8-3 mm compr., lineares, tomentosas; folha pinada, paripinada; nectários foliares ausentes; pecíolo 1,6-2 cm compr., canaliculado, tomentoso; raque 15,5-22 cm compr., canaliculada, tomentosa; folíolos 15-31 pares, 1,9-2,8 × 0,7-0,9 cm, oblongos, ápice agudo, base assimétrica, face adaxial puberulenta, face abaxial pubescente. Inflorescências racemosas, axilares, pêndulas; pedúnculo 0,5-1 cm compr.; raque 7,5-16 cm compr., estriada, esparso-tomentosa; brácteas 4-6 mm compr., lanceoladas, tomentosas; flores pentâmeras, zigomorfas; cálice 1,1-1,2 cm compr., dialissépalo, pubescente; corola $2 \mathrm{~cm}$ compr., dialipétala; estames maiores 3 , filetes $1,7-2,3 \mathrm{~cm}$ compr., sigmóides, anteras $3 \mathrm{~mm}$ compr., estames menores 4 , filetes $0,8-1 \mathrm{~cm}$ compr., retos, anteras 3 mm compr., estaminódios 3; ovário 2-2,3 cm compr., pubescente, curvo; estilete 1-1,5 mm compr., reto, pubescente; estigma terminal, punctiforme, ciliado. Lomento drupáceo, $26-43 \times 2 \mathrm{~cm}$, subcilíndrico, indeiscente, glabro; 50-65 sementes, $5 \times 7 \mathrm{~mm}$, elípticas, avermelhadas.

Material selecionado: BRASIL. Minas Gerais: Araponga, Fragmento da Eva, 28-IV-2006, fr., J.M. Fernandes 264 (VIC); Fragmento da Lurdinha, 28-X-2006, fl., J.M. Fernandes 390 (VIC).

Cassia ferruginea é reconhecida na área de estudo por apresentar flores com estames sigmóides e fruto do tipo lomento drupáceo. A espécie ocorre nos estados do Ceará, Bahia, Tocantins, Goiás, Minas Gerais, Rio de Janeiro e Paraná, ocupando ambientes de cerrado, restinga e floresta atlântica (Irwin \& Barneby 1982). Nos fragmentos estudados ocorre principalmente em áreas pouco alteradas no interior da vegetação. Floresceu em outubro e frutificou em abril.

Senna Mill., Gard. Dict. Abr., ed. 4, 3: Senna. 1754.

Árvores, arbustos ou subarbustos. Folhas pinadas, paripinadas; estípulas presentes, estipelas ausentes; nectário foliar presente no pecíolo ou entre os pares de folíolos, às vezes ausentes; folíolos opostos, raramente subopostos; nervação peninérvea.
Inflorescências racemosas ou paniculadas, multifloras até bifloras, axilares ou terminais; brácteas presentes e bractéolas ausentes; flores pentâmeras, zigomorfas ou levemente assimétricas; hipanto quase inexistente; cálice dialissépalo, esverdeado ou amarelado; corola dialipétala, amarela; androceu dialistêmone, 7 estames férteis, heterodínamos, 3 maiores adaxiais, 4 menores medianos, 3 estaminódios abaxiais; ovário pluriovulado. Fruto legume bacóide, deiscente, raramente indeiscente; sementes compressas, geralmente areoladas.

2. Senna macranthera var. nervosa (Vogel) H.S. Irwin \& Barneby, Mem. New York Bot. Gard. 35(1): 181. $1982 \equiv$ Cassia nervosa Vogel, Gen. Cass. Syn.: 39. 1837.

Figura 2c-d

Árvores 7-8 m alt.; ramos jovens tomentosos. Estípulas 2-2,5 mm compr., lineares a lanceoladas, pubescentes; pecíolo 2,7-4,7 cm compr., canaliculado, tomentoso; raque 2-2,5 cm compr., canaliculada, pubescente; nectários piriformes, sésseis a subsésseis, entre os pares de folíolos; folíolos 2 pares, 6-12 $\times$ 2-5,2 cm, ovado-elípticos a falcados, ápice agudo a acuminado, base oblíqua, face adaxial esparso-serícea, face abaxial serícea. Inflorescências paniculadas, axiais ou terminais; pedúnculo 3-4 cm compr., pubescente; raque 2-7 cm compr., canaliculada, esparso-tomentosa; brácteas 3,3-4,5 × 1,9-2,6 mm, lanceoladas, esparso-tomentosas; flores zigomorfas; cálice 4-7 mm compr., pubescente externamente; corola 3,3-4,5 cm compr.; estames maiores 3, filetes 13-18 mm compr., anteras 8-10 mm compr., estames menores 4, filetes 9-10 mm compr., anteras 6-8 mm compr., 3 estaminódios adaxiais; ovário 2,5-4 cm compr., curvo, esparso seríceo; estilete 3,4 mm compr., seríceo; estigma lateral, truncado, ciliado. Legume bacóide 30-40 × $1 \mathrm{~cm}$, cilíndrico, coriáceo; 150-170 sementes, 6-6,5 $\times 5 \mathrm{~mm}$, orbiculares, avermelhadas.

Material selecionado: BRASIL. Minas Gerais: Araponga, Fragmento da Lurdinha, 25-II-2006, fl., J.M. Fernandes et al. 184 (VIC).

Material adicional examinado: BRASIL. MinAs GERAIS: Araponga, SAF do Romualdo, 5-IX-2005, fr., J.M. Fernandes 16 (VIC).

Senna macranthera var. nervosa é reconhecida na área de estudo por apresentar folhas com dois pares de folíolos e presença de nectários piriformes entre eles, enquanto que Senna multijuga, possui de 12 a 
45 pares de folíolos e apenas 1 nectário fusiforme entre o primeiro par de folíolos. A espécie ocorre no Brasil, Colômbia, Equador, Peru e Venezuela. No Brasil, está distribuída nos estados da Bahia, Espírito Santo, Goiás, Minas Gerais, Rio de Janeiro e São Paulo (Irwin \& Barneby 1982). A espécie está pouco representada nos dois fragmentos, ocorrendo em áreas pouco alteradas. Floresceu de fevereiro a maio, e foi coletada com fruto em setembro.

3. Senna multijuga (Rich.) H.S. Irwin \& Barneby, Mem. New York Bot. Gard. 35: 492. $1982 \equiv$ Cassia multijuga Rich. Actes Soc. Hist. Nat. Paris 1: 108. 1792.

Figura 2e-f

Árvores 3-8 m alt.; ramos jovens tomentosos. Estípulas 3,5-8 mm compr., lineares, tomentosas; pecíolo 0,8-2,2 cm compr., canaliculado, tomentoso; raque $10-22 \mathrm{~cm}$ compr., canaliculada, tomentosa; nectário foliar fusiforme, subséssil a estipitado, entre o primeiro par de folíolos; folíolos 12-45 pares, 1,4-3 × 0,3-0,9 cm, oblongo-falcados a linear-falcados, ápice arredondado a agudo, base assimétrica, faces adaxial e abaxial seríceas. Inflorescências racemosas; pedúnculo 2,2-3 cm compr.; brácteas 3-5 × 2-2,2 mm, lanceoladas, pubescentes; cálice 3,5-5 $\mathrm{mm}$ compr., pubescente externamente; corola assimétrica, 1,8-2,6 cm compr.; estames maiores 3 , filetes 0,9-2,6 cm compr., anteras 7-8 $\mathrm{mm}$ compr., estames medianos 4, filetes 6-7 mm compr., anteras 1,5-2 mm compr., 3 estaminódios adaxiais; gineceu estipitado; estípite 2-3 mm compr., seríceo; ovário 1-1,6 cm compr., esparso-seríceo, curvado; estilete $1,5 \mathrm{~mm}$ compr., glabro; estigma lateral, truncado, ciliado. Legume 6-16,5 × 1,7-2 cm, plano compresso, glabro a glabrescente; $10-40$ sementes, $8-9 \times 3 \mathrm{~mm}$, oblongas, areoladas, enegrecidas.

Material selecionado: BRASIL. Minas Gerais: Araponga, Fragmento da Lurdinha, 26-III-2006, fl., J.M. Fernandes et al. 240 (VIC); 28-VI-2006, fr., J.M. Fernandes 303 (VIC).

A espécie é encontrada na Ilha de Java e Sumatra na Ásia, Costa Rica, Honduras, México, Panamá, América Central (incluindo o Caribe); e na América do Sul, ocorre no sul da Bolívia, Brasil, Colômbia, Equador, Guiana Francesa, Guiana, Peru, Suriname e Venezuela (ILDIS 2008). No Brasil, ocorre no Amazonas, Bahia, Espírito Santo, Goiás, Minas Gerais, Paraná, Rio de Janeiro, Santa Catarina e São Paulo
(Irwin \& Barneby 1982). Está pouco representada nos fragmentos. Floresceu de janeiro a abril, e frutificou de abril a julho.

Tachigali Aubl., Hist. Pl. Guiane 1: 372, pl. 143. 1775.

Árvores. Folhas pinadas, paripinadas; estípulas caducas, estipelas ausentes; nectários foliares ausentes; folíolos opostos, raramente subopostos; nervação peninérvea. Inflorescências paniculadas, axilares ou terminais; brácteas decíduas e bractéolas ocasionalmente persistentes; flores pentâmeras, actinomorfas; hipanto presente; cálice dialissépalo, esverdeado; corola dialipétala, pétalas lineares ou lanceoladas, amarela ou branca; androceu dialistêmone, 10 estames, heterodínamos, estaminódios ausentes; ovário pluriovulado, estipitado. Fruto criptossâmara, indeiscente; sementes na região central.

4. Tachigali friburgensis (Harms) L.G. Silva \& H.C. Lima, Rodriguésia 58(2): 397. 2007 ESclerolobium friburgense Harms, Repert. Spec. Nov. Regni Veg. 24: 211. 1928.

Figura 2g-i

Árvores 8-10 m alt.; ramos jovens esparsotomentosos. Estípulas 1-1,5 cm compr., rombóides, esparso-tomentosas; pecíolo 2,5-3,6 cm compr., triangular, esparso-tomentoso a puberulento; raque 7,5-14 cm compr., canaliculada, esparso-tomentosa a puberulenta; folíolos 5-7 pares, 4-15 × 2,8-8,3 cm, elípticos a obovado-subfalcados, ápice agudo, raramente acuminado, base obtusa, face adaxial esparso-tomentosa, face abaxial densamente canescente-tomentosa, nervuras terciárias inconspícuas. Inflorescências terminais; pedúnculo 2-3 mm compr.; raque 1,5-5,5 cm compr., estriada, esparsotomentosa; brácteas caducas; bractéolas 3-4x 0,6-0,8 mm, lanceoladas, pubescentes; cálice 2,6-3 mm compr., tomentoso externamente, lanoso internamente; corola 2,8-3,6 mm compr., pétalas lineares, esparsotomentosas; filetes $2,4-5 \mathrm{~mm}$ compr., filamentos ferrugíneos na base, anteras 1,2-1,8 mm compr.; gineceu estipitado; estípite 5-8 mm compr., tomentoso; ovário 2-3 mm compr., tomentoso; estilete $8-9 \mathrm{~mm}$ compr., glabro; estigma terminal, cilíndrico, glabro. Criptossâmara 8-9 × 3,5-3,7 cm, plano compresso, puberulento; 1-2 sementes, 1,4-1,7 × 1-1,2 cm, oblongas, avermelhadas.

Material selecionado: BRASIL. Minas Gerais: Araponga, Fragmento da Eva, 23-XI-2005, fr., J.M. 
Fernandes 98 (VIC); 16-XII-2006, fl., J.M. Fernandes 397 (VIC).

Tachigali friburgensis distingue-se de T. rugosa por apresentar 5-10 pares de folíolos, indumento canescente na face abaxial, nervuras terciárias inconspícuas e estilete com até $0,9 \mathrm{~mm}$ compr., enquanto que a segunda espécie possui 5-7 pares de folíolos, face abaxial densamente áureo-tomentosa, nervuras terciárias conspícuas e estilete com 1,5-2 mm compr. E a terceira espécie, T. paratyensis, é facilmente reconhecida por apresentar de 14-16 pares de folíolos elípticos a subfalcados. No Brasil, é citada a ocorrência para os Estados do Rio de Janeiro (Dwyer 1957), Amazonas, São Paulo e Minas Gerais. Nos fragmentos está bem representada, ocorrendo em áreas do entorno e no interior da floresta. Floresceu de novembro a janeiro, e foi coletada com frutos em novembro.

5. Tachigali paratyensis (Vell.) H.C.Lima, Acta Bot. Brasil. 9: 128. 1995 三Cassia paratyensis Vell., Fl. Flumin. 168. 1825.

Figura 21-m

Árvores 13-15 m alt.; ramos jovens esparsotomentosos. Estípulas ca. $1 \mathrm{~cm}$ compr., elípticas, glabrescentes; pecíolo 3-4,5 cm compr., canaliculado, esparso-tomentoso; raque $24-28 \mathrm{~cm}$ compr., canaliculada, esparso-tomentosa; folíolos 14-16 pares, 5-12,5 × 1,7-3,5 cm, elípticos a subfalcados, ápice agudo a acuminado, base oblíqua, faces adaxial e abaxial glabrescentes. Flores não observadas. Criptossâmara ca. $5 \times 2,5 \mathrm{~cm}$, plano compresso, glabrescente; sementes não observadas.

Material selecionado: BRASIL. Minas Gerais: Araponga, Fragmento da Eva, 28-XII-2006, fr., J.M. Fernandes 384 (VIC).

Ocorre nos Estados do Amazonas, São Paulo, Rio de Janeiro (Dwyer 1954), Minas Gerais, Espírito Santo e Bahia (Oliveira Filho 2006). Foi observado apenas um indivíduo em cada fragmento; segundo moradores locais esta planta é muito procurada para fazer tábua. O período de floração não foi observado, mas foi coletada com frutos em outubro.

6. Tachigali rugosa (Mart. ex Benth.) Zarucchi \& Pipoly, Sida 16(3): 411. 1995 इSclerolobium rugosum Mart. ex Benth., Hooker's J. Bot. Kew Gard. Misc. 2: 237. 1850.

Figura $2 \mathrm{j}-\mathrm{k}$
Árvores 13-15 m alt.; ramos jovens tomentosos. Estípulas 5-7 mm compr., foliáceas, esparsotomentosas; pecíolo 2-5 cm compr., estriado, tomentoso; raque 15,5-20 cm compr., plana a canaliculada, tomentosa; folíolos 5-7 pares, 4-11 $\times$ $1,8-4,5 \mathrm{~cm}$, estreitamente oblongos, ápice agudo, base obtusa a levemente oblíqua, face adaxial glabrescente, face abaxial densamente áureo-tomentosa, nervuras terciárias conspícuas. Pedúnculo 0,5-1 cm compr.; raque 3,5-6 cm compr., estriada, tomentosa; cálice 2,3-3,5 mm compr., glabrescente; corola 2,6-3,5 mm compr., pétalas lineares, glabrescentes, esverdeadas; filetes 4-5 mm compr., filamentosos até a metade dos filetes; anteras 1,4-1,6 mm compr.; ovário 2,8-3,2 mm compr., reto, tomentoso na base, glabro no restante; estilete 1,5-2 mm compr.; estigma terminal cilíndrico, glabro. Criptossâmara 8-11 ×3,5-4 cm, elípticos, glabro; 1 semente, 9-1 $\times 1,1$, amplo-circular, esverdeadas.

Material selecionado: BRASIL. Minas Gerais: Araponga, Fragmento da Lurdinha, 28-X-2006, fl., J.M. Fernandes 388 (VIC); 17-11-2007, fr., J.M. Fernandes 533 (VIC).

Ocorre na Bolívia e no Brasil, nos Estados de Mato Grosso, Minas Gerais, Goiás, Bahia, Tocantins (Oliveira Filho 2006), e Rio de Janeiro (Dwyer 1957). Foi observado apenas um indivíduo adulto no entorno do Fragmento da Lurdinha. Floresceu em outubro e frutificou em novembro.

Subfamília Mimosoideae

7. Abarema obovata (Benth.) Barneby \& J.W. Grimes, Mem. New York Bot. Gard. 74(1): 91.1996 $\equiv$ Calliandra obovata Benth., London J. Bot. 3: 101.1844.

Figura 2n-p

Árvores 2-5 m alt.; ramos jovens esparsotomentosos. Estípulas 3,5-5 mm compr., lanceoladas, tomentosas; folha bipinada, paripinada; pecíolo 1,2-2,6 cm compr., estriado, tomentoso; nectário foliar pateliforme, séssil; raque $2,8-8 \mathrm{~cm}$ compr., estriada, tomentosa; pinas 2-4 pares, foliólulos 2-5 pares, 1,2-3,6 × 0,8-2,2 cm, ovado-rombóides ou rombóides, ápice obtuso, base oblíqua, face adaxial glabrescente, face abaxial glabra. Inflorescências umbeliformes, axilar; pedúnculo 2,1-5 cm compr.; brácteas $1-5 \times 0,8 \mathrm{~mm}$, ovadas, pubescentes; raque $6-7 \mathrm{~mm}$ compr.; flores pentâmeras; cálice 2-2,5 mm compr., gamossépalo, infundibuliforme, pubescente 

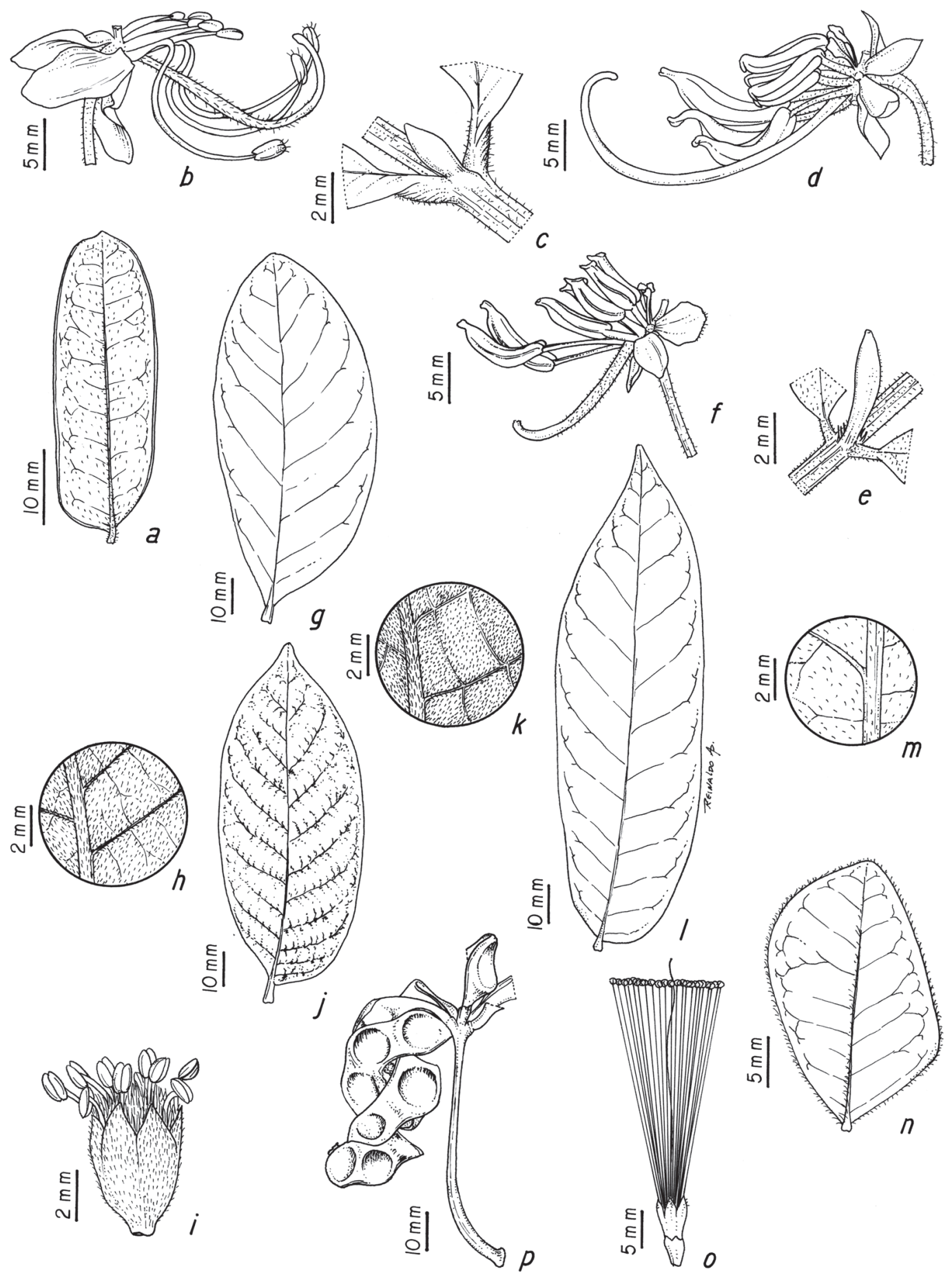

Figura 2. a-b. Cassia ferruginea. a. Folíolo. b. Flor sem pétalas. c-d. Senna macranthera. c. Nectário foliar. d. Flor sem pétalas. e-f. Senna multijuga. e. Nectário foliar. f. Flor sem pétalas. g-i. Tachigali friburgensis. g. Folíolo. h. Indumento da face abaxial do folíolo. i. Flor. j-k. Tachigali rugosa. j. Folíolo. k. Indumento da face abaxial do folíolo. 1-m. Tachigali paratyensis. 1. Folíolo. m. Indumento da face abaxial do folíolo. n-p. Abarema obovata. n. Foliólulo. o. Flor. p. Fruto (a, b: Fernandes et al. 390; c, d: Fernandes et al. 244; e, f: Fernandes et al. 240; g-i: Fernandes 417; k: Fernandes 388; 1, m: Fernandes 384; n, o: Fernandes 232; p: Fernandes 401).

Figure 2. a-b. Cassia ferruginea. a. Leaflet. b. Flower without petals. c-d. Senna macranthera. c. Leaf nectary. d. Flower without petals. e-f. Senna multijuga. e. Leaf nectary. f. Flower without petals. g-i. Tachigali friburgensis. g. Leaflet. h. Indument of abaxial leaflet surface. i. Flower. j-k. Tachigali rugosa. j. Leaflet. k. Indument of abaxial leaflet surface. 1-m. Tachigali paratyensis. 1. Leaflet. m. Indument of abaxial leaflet surface. n-p. Abarema obovata. n. Leaflets. o. Flower. p. Fruit (a, b: Fernandes et al. 390; c, d: Fernandes et al. 244 ; e, f: Fernandes et al. 240; g-i: Fernandes 417; k: Fernandes 388; 1, m: Fernandes 384; n, o: Fernandes 232; p: Fernandes 401). 
externamente; corola 7-7,8 mm compr., gamopétala, infundibuliforme, tomentosa nas extremidades das pétalas; estames 21-36, brancos, 33-37 mm compr., tubo 4-8 mm compr., incluso; gineceu estipitado; estípite 1,7-1,8 mm compr.; ovário 1,2-1,5 mm compr., tomentoso; estilete 30-33 mm compr., reto, glabro; estigma terminal, punctiforme, glabro. Legume 8-9 $\times$ 1,2-1,5 cm, plano compresso, glabrescente; 7-9 sementes, 6-7 × 5-6 mm, circular a oblata, azul e branca.

Material selecionado: BRASIL. Minas Gerais: Araponga, Fragmento da Eva, 26-III-2006, fl., J.M. Fernandes 232 (VIC); 19-VIII-2006, fr., J.M. Fernandes 367 (VIC).

Abarema obovata é reconhecida na área de estudo por apresentar foliólulos ovado-rombóides a rombóides, fruto legume circinado e sementes bicolores, azuis e brancas. Sua ocorrência é restrita ao Brasil, especificamente ao estado de Minas Gerais em áreas de floresta estacional semidecidual (Barneby \& Grimes 1996). Floresceu de março a maio e frutificou de julho a outubro.

8. Acacia martiusiana (Steud.) Burkart, Fl. Il. Catarin., fasc. Legu: 30. $1979 \equiv$ Mimosa martiusiana Steud., Nom. Bot. 2(2): 148. 1841.

Figuras: 3a-d

Lianas; ramos jovens tomentosos, aculeados. Estípulas 3,5-5 mm compr., lineares, esparsotomentosas; folha bipinada, paripinada; pecíolo 1,2-1,5 cm compr., estriado, tomentoso; nectário cupuliforme, estipitado, presente no pecíolo e entre os pares de pinas; raque 10-14 cm compr., estriada, aculeada; pinas 18-24 pares, foliólulos 44-71 pares, 3,2-4,5 $\times 0,5-0,9 \mathrm{~mm}$, lineares, ápice agudo, base oblíqua ou truncada, faces adaxial e abaxial glabras. Inflorescências capituliformes, agrupadas em panículas terminais; pedúnculo 1-1,4 cm compr.; raque 3-4 mm compr., estriada, tomentosa; brácteas 1-1,2× 0,2-0,3 mm, espatuladas, pubescentes; bractéolas $0,8-1 \times 0,2-0,3 \mathrm{~mm}$, espatuladas, pubescentes; flores sésseis a subsésseis, pentâmeras, actinomorfas; cálice 2,3-2,5 mm compr., gamossépalo, campanulado, pubescente externamente; corola $3 \mathrm{~mm}$ compr., gamopétala, campanulada, glabra; ca. 61-70 estames, $7 \mathrm{~mm}$ compr., cremes, concrescido na base; gineceu estipitado; estípite 0,8-1 mm compr., glabro; ovário $1 \mathrm{~mm}$ compr., glabro; estilete 7-8 mm compr., reto, glabro; estigma terminal, capitado. Legume 11,5-15 $\times$
1,5-2,5 cm, plano compresso, glabro; 7-9 sementes, $1 \times 0,8-0,9 \mathrm{~cm}$, arredondadas, avermelhadas.

Material selecionado: BRASIL. Minas Gerais: Araponga, Fragmento da Lurdinha, 25-II-2006, fl., J.M. Fernandes 186 (VIC); 5-X-2005, fr., J.M. Fernandes 66 (VIC).

Acacia martiusiana é reconhecida por apresentar nectário cupuliforme estipitado no pecíolo e entre os pares de pinas e com 44-71 foliólulos por pina. Ocorre nos estados da Bahia (Lewis 1987), Rio de Janeiro, Paraná, Santa Catarina (Burkart 1979) e Minas Gerais (Lima et al. 2007). Foi amostrada apenas no entorno do Fragmento da Lurdinha, principalmente em áreas alteradas. Floresceu de março a maio e frutificou de junho a novembro.

Inga Mill., Gard. Dict. Abr. ed. 4. 1754.

Árvores ou arbustos. Ramos inermes. Folhas pinadas, paripinadas; estípulas persistentes ou caducas; pecíolo cilíndrico ou alado; raque geralmente alada; nectário foliar presente entre os folíolos de todos os pares, ou ausente em alguns pares; folíolos 2-7 pares, opostos. Inflorescências plurifloras, racemosas ou espiciformes, homomórficas; cálice gamossépalo, tubular a campanulado, 5-7 sépalas; corola gamopétala, tubular, infundibuliforme ou campanulada, 5-7 pétalas; androceu monadelfo formando um tubo, polistêmone, brancos ou rosados; gineceu mono a pluricarpelar, ovário monocarpelar, pluriovulado. Fruto legume nucóide, plano compresso, cilíndrico ou quadrangular, margens estreitas ou espessas, estriadas longitudinalmente; semente com sarcotesta carnosa, adocicada, comestível.

9. Inga cylindrica (Vell.) Mart., Flora 20(2): Beibl. 114. 1837 =Mimosa cylindrica Vell., Fl. Flumin. 11: pl. 9. 1835.

Figura 3e-g

Árvores 10-12 m alt.; ramos jovens castanhotomentosos. Estípulas $3 \mathrm{~mm}$ compr., lanceoladas ou ovadas, esparso-tomentosas, caducas; pecíolo 1,8-3,2 cm compr., cilíndrico, glabrescente; raque 4-8,4 cm compr., cilíndrica, glabrescente; nectário foliar pateliforme; folíolos 4-5 pares, 2,2-7,6 0 0,8-2,4 cm, elípticos, ápice acuminado, base atenuada, faces adaxial e abaxial glabrescentes. Inflorescências espiciformes, axilares; pedúnculo 1-2 cm compr.; raque 1,9-3,5 cm compr., cilíndrica, estriada, pubescente; brácteas 5-11 ×2-9 mm, ovadas, pubescentes, caducas; 
flores sésseis, pentâmeras; cálice 1,5-1,8 mm compr., campanulado, glabrescente externamente; corola 3,1-4,3 mm compr., campanulada, tomentosa no ápice; 24-30 estames, 10-12 mm compr., brancos, tubo estaminal 5-7,1 mm compr., exserto; ovário 1-1,2 mm compr., glabro; estilete 10-11 mm compr., reto, glabro; estigma terminal, infundibuliforme, glabro. Legume $14-26 \times 1,7-2 \mathrm{~cm}$, reto a levemente curvado, plano compresso, glabro; ca. 11 sementes, ca. $12-7 \mathrm{~mm}$, túrgidas.

Material selecionado: BRASIL. Minas Gerais: Araponga, Fragmento da Lurdinha, 23-XI-2005, fl., J.M. Fernandes et al. 97 (VIC); 25-II-2006, fr., J.M. Fernandes 175 (VIC).

Inga cylindrica diferencia-se das outras espécies encontradas na área de estudo por apresentar raque foliar cilíndrica, inflorescência espiciforme e corola com até 4,3 mm compr. Está distribuída na Costa Rica, Colômbia, Equador, Peru, Bolívia, Guiana Francesa e Brasil (Pennington 1997). Na região costeira do Brasil, foi registrada nos Estados da Bahia, Minas Gerais, Rio de Janeiro e São Paulo (Garcia 1998). Na região norte, é encontrada nos Estados do Amazonas, Tocantins e Pará (Pennington 1997). Nos fragmentos ocorre tanto no entorno como no interior da floresta. Floresceu de outubro a dezembro e frutificou de fevereiro a abril.

10. Inga platyptera Benth., London J. Bot. 4: 602. 1845. Figura 3h-k

Árvores 2-4 m alt.; ramos jovens hirsutos. Estípulas 10-17 × 3-4 mm, ovadas, seríceas; pecíolo $2-3,7 \mathrm{~cm}$ compr., alado, hirsuto; raque $7-10,5 \mathrm{~cm}$ compr., alada, hirsuta; nectário foliar funiliforme, geralmente presente em todos os pares de folíolos; folíolos 2-4 pares, 2,8-15,7 × 1-3,1 cm, lanceolados a elípticos, ápice longo atenuado a agudo, base atenuada, faces adaxial e abaxial hirsutas. Inflorescências racemosas congestas, axilares; pedúnculo $3-3,5 \mathrm{~cm}$ compr.; raque $2 \mathrm{~cm}$ compr., estriada, serícea; brácteas 1,5-2 $\times 0,4-0,5 \mathrm{~cm}$, lanceoladas, hirsutas, persistentes; flores sésseis, pentâmeras; cálice 0,9-1 cm compr., tubular, hirsuto, sem estrias; corola 1,7-2 cm compr., tubulosa, hirsuta; 74-78 estames, 3,4-4,2 cm compr., brancos, tubo estaminal 1-1,4 cm compr., incluso; ovário 1,5-2 mm compr., glabro; estilete 3-3,6 cm compr., reto, glabro; estigma terminal, infundibuliforme, glabro. Legume 10-13,5 × 1,2-2,3 cm, reto, plano compresso, margem estreita, hirsuto; 7-10 sementes,
$1,3 \times 0,8 \mathrm{~cm}$, oblongas, sarcotesta abundante.

Material selecionado: BRASIL. Minas Gerais: Araponga, Fragmento da Eva, 13-XII-2005, fl., J.M. Fernandes 111 (VIC); 13-XII-2005, fr., J.M. Fernandes 117 (VIC).

Inga platyptera é reconhecida na área de estudo pela presença de folíolos estreitos e longos, nectários foliares funiliformes e estipitados. Ocorre nos Estados do Espírito Santo, Rio de Janeiro e Minas Gerais (Garcia \& Fernandes 2010). No Fragmento da Eva ocorre em áreas do interior (subosque) e entorno. Floresceu de dezembro a fevereiro e frutificou de outubro a dezembro.

11. Inga sessilis (Vell.) Mart., Flora 20(2): Beibl. 114. $1837 \equiv$ Mimosa sessilis Vell., Fl. Flumin. 11: pl. 21. Figura 31-n

Árvores 3-5 m alt.; ramos jovens ferrugíneovilosos. Estípulas 3,4-9 mm compr., elípticas, velutinas; pecíolo 1,8-2,8 cm compr., alado, velutino; raque 13,5-16,7 cm compr., alada, velutina; nectários foliares cupuliforme-compressos, sésseis; folíolos 6-7 pares, 6-14× 2,6-5,1 cm, elíptico-ovados, ápice agudo, base arredondada, faces adaxial e abaxial velutinas. Inflorescências racemosas congestas, axilares; pedúnculo 2,5-3,7 cm compr.; raque 1,1-3,8 cm compr., estriada, velutina; brácteas $8-10 \times 7-9 \mathrm{~mm}$ ovadas, vilosas; flores sésseis a subsésseis; cálice 3-5 sépalas, 1,7-2,6 cm compr., campanulado, tomentoso externamente; corola 5 sépalas, 2,7-4 cm compr., campanulada, tomentosa; $260-273$ estames, $8-10 \mathrm{~cm}$ compr., brancos, tubo estaminal $2,5 \mathrm{~cm}$ compr., incluso; estilete $12 \mathrm{~cm}$ compr., reto, glabro; ovário $4-5 \mathrm{~mm}$ compr., glabro; estigma terminal, infundibuliforme, glabro. Legume $12,8-15 \times 3 \mathrm{~cm}$, curvado, plano, margem velutino-tomentoso; 16 sementes, 1,4-1,5 $\times$ 0,6-0,8 cm, elípticas, sarcotesta abundante.

Material selecionado: BRASIL. Minas Gerais: Araponga, Fragmento da Lurdinha, 25-II-2006, fl., J.M. Fernandes et al. 192 (VIC); 16-XII-2006, fr., J.M. Fernandes 409 (VIC).

Inga sessilis é reconhecida na área de estudo por apresentar 6-7 pares de folíolos, flores grandes com cálice 1,7-2,6 cm compr., e frutos curvos. Ocorre do Espírito Santo até o Rio Grande do Sul, sendo comum em floresta ombrófila densa submontana e montana, acima dos $400 \mathrm{~m}$ de altitude, nas florestas estacionais semideciduais montanas, que cobrem parte 
da Serra da Mantiqueira, e nas florestas de araucária do Paraná, Santa Catarina e Rio Grande do Sul (Garcia 1998). A espécie está pouco representada na área de estudo, ocorrendo apenas no Fragmento da Lurdinha em áreas do entorno. Floresceu de janeiro a setembro, e frutificou de junho a dezembro.

12. Inga striata Benth., London J. Bot. 4: 608. 1845. Figura 3o-q

Árvore ca. $8 \mathrm{~m}$ alt.; ramos jovens castanhovilosos. Estípulas 2-10 mm compr., falciformes ou elípticas, vilosas; pecíolo 2,4-4 cm compr., cilíndrico, viloso; raque 7,5-16,2 cm compr., alada, vilosa; nectário pateliforme; folíolos 4-5 pares, 4-12,5 × 1,5-4,2 cm, elíptico-ovado, ápice atenuado, base obtusa, faces adaxial e abaxial vilosas, com tricomas glandulares na face abaxial. Inflorescências espiciformes congestas, axilares; pedúnculo 2-2,8 cm compr.; raque 1,2-1,6 cm compr., estriada, vilosa; flores sésseis, pentâmeras; cálice 8-9,5 mm compr., tubular, estriado longitudinalmente, seríceo; corola 1,3-1,6 cm compr., tubular, serícea externamente; 41-45 estames, 2,8-3,5 cm compr., brancos, tubo estaminal 6-7 mm compr., incluso; ovário 2-2,5 mm compr., glabro; estilete 2,3-3,7 cm compr., glabro; estigma terminal, funiliforme, glabro. Legume 13,2-16,3 × 1,4-1,6 cm, retos a levemente curvados, face plana, margem expandida, ferrugíneo-viloso; sementes não observadas.

Material selecionado: BRASIL. Minas Gerais: Araponga, Fragmento da Lurdinha, 27-I-2005, fr., J.M. Fernandes 133 (VIC); 28-X-2006, fl., J.M. Fernandes 391 (VIC).

Inga striata diferencia-se das outras espécies de Inga que ocorrem na área de estudo pelo cálice estriado longitudinalmente. Está distribuída na América do Sul, do oeste da Amazônia até a Bolívia, ao norte, na Guiana Francesa e, a leste, ao longo da costa brasileira, penetrando no continente na região Sul e Sudeste do país (Garcia 1998). No Sul e Sudeste do Brasil, chega até a floresta estacional semidecidual que corta o cerrado e é encontrada com alta frequência inclusive em vegetação secundária (Garcia 1998). Floresceu de outubro a novembro, e frutificou em janeiro.

Piptadenia Benth., J. Bot. (Hooker) 2(11): 135. 1840.

Árvores, arbustos ou lianas. Ramos inermes ou armados. Folhas bipinadas, paripinadas; estípulas caducas; pecíolo cilíndrico a canaliculado; raque desprovida de alas; nectários foliares presentes no pecíolo e/ou entre os primeiros pares de pinas; folíolos 1-17 pares por pina, opostos a subopostos. Inflorescências espiciformes, axilares ou terminais, homomórficas; flores pentâmeras; cálice gamossépalo, campanulado; corola concrescida na base; androceu diplostêmone, filetes livres; ovário pluriovulado. Fruto legume, plano compresso, deiscente; sementes lenticulares com pleurograma.

13. Piptadenia adiantoides (Spreng.) J.F. Macbr., Contr. Gray Herb. 59: 17. 1919 三Acacia adiantoides Spreng., Syst. Veg. 3: 146. 1826.

Figura 4a-b

Lianas; ramos jovens esparso-tomentosos, armados. Estípulas 3-4 mm compr., lineares, esparsotomentosas; pecíolo 4,6-7,2 cm compr., canaliculado, pubescente, acúleos recurvos; raque 5,3-10 cm compr., canaliculada, aculeada; nectário foliar verruciforme, séssil, presente no pecíolo e raque; pinas 4 pares, foliólulos 2-5 pares por pina, 1,4-3,8 $\times$ 0,9-1,6 cm, elípticos a subfalcados, ápice agudo, base oblíqua, faces adaxial e abaxial vilosas, nervura principal submarginal. Inflorescências espiciformes, axilares; pedúnculo 4-7 $\mathrm{mm}$ compr.; raque $8-9 \mathrm{~cm}$ compr., estriada, tomentosa; brácteas não observadas; bractéolas 0,8-1 ×0,2 mm, lanceoladas, pubescentes; flores sésseis a subsésseis, pentâmeras; cálice 1-1,5 mm compr., pubescente; corola $3 \mathrm{~mm}$ compr., glabra; estames $5 \mathrm{~mm}$ compr., filetes brancos a rosados; gineceu estipitado; estípite 1,5-2 mm compr., glabro; ovário 1,5 mm compr., pubescente na região distal; estiletes 3-4 mm compr., retos, glabros; estigma terminal, cilíndrico, glabro. Legume 13-17×2,4-2,6 cm, reto, plano compresso, margens sinuosas, valvas cartáceas, glabrescente; 7-10 sementes, 6-9 ×5-6 mm, oblongas, amarronzadas.

Material selecionado: BRASIL. Minas Gerais: Araponga, Fragmento da Lurdinha, 5-X-2005, fr., J.M. Fernandes 84 (VIC); 28-VI-2006, fl., J.M. Fernandes 273 (VIC).

Piptadenia adiantoides distingue-se de P. micracantha na área de estudo por apresentar exatamente 4 pares de pinas, possuindo cada uma 2-5 pares de foliólulos e filetes brancos, enquanto que $P$. micracantha possui 11-17 pares de pinas, na qual cada uma possui 34-40 pares de foliólulos e filetes avermelhados. Espécie restrita ao Brasil; ocorre desde a Bahia até o Paraná, em floresta de encosta, restinga, áreas de plantações de cacau e vegetação graminosa 


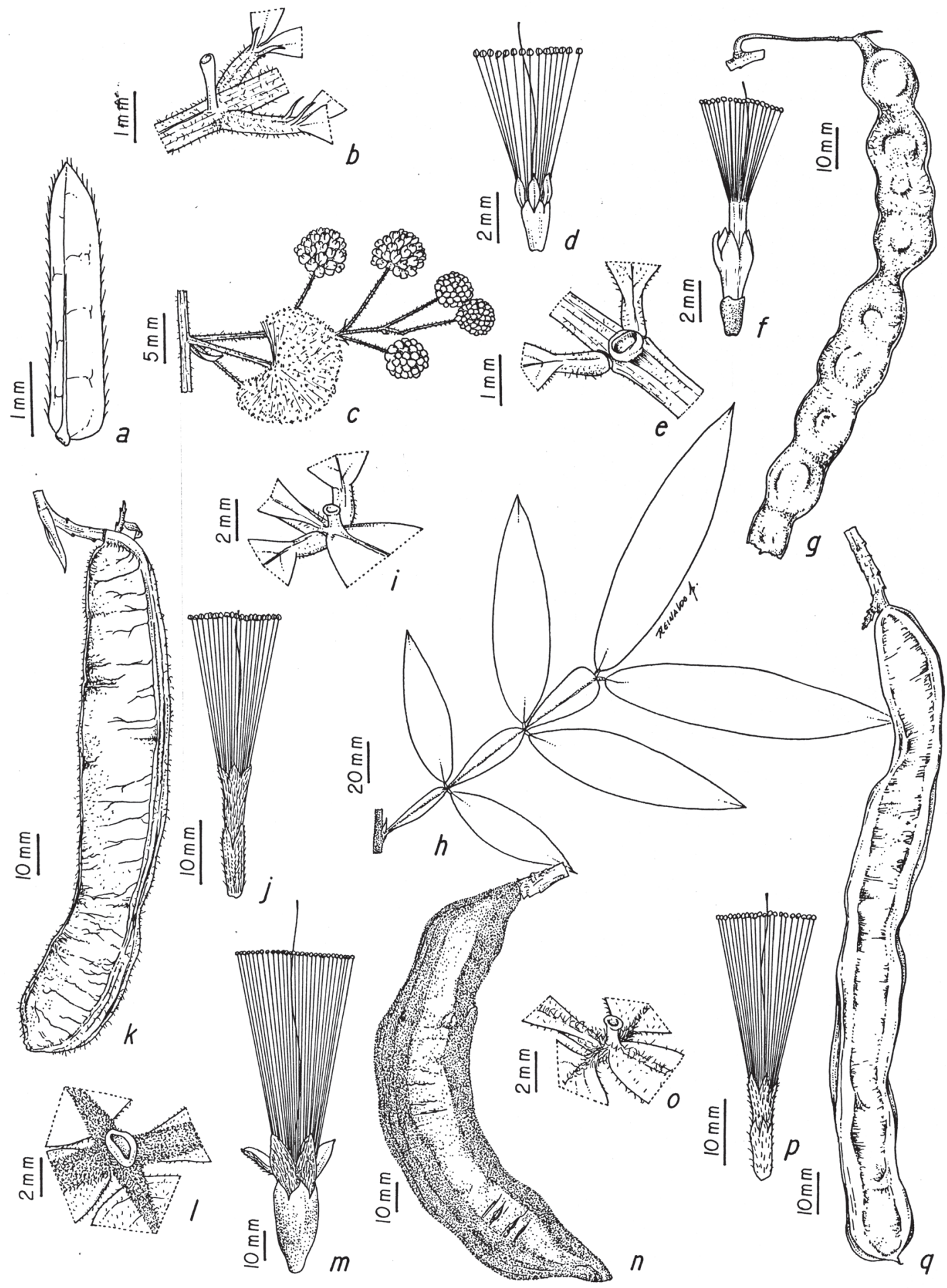

Figura 3. a-d. Acacia martiusiana. a. Foliólulo. b. Nectário foliar. c. Inflorescência. d. Flor. e-g. Inga cylindrica. e. Nectário foliar. f. Flor. g. Fruto. h-k. Inga leptantha. h. Folha. i. Nectário foliar. j. Flor. k. Fruto. 1-n. Inga sessilis. 1. Nectário foliar. m. Flor. n. Fruto. o-q. Inga striata. o. Nectário foliar. p. Flor. q. Fruto (a-d: Fernandes 324; e, f: Fernandes et al. 97; g: Fernandes 175; h-j: Fernandes 111; k: Fernandes 117; 1, m: Fernandes et al. 192; n: Fernandes 304; o, p: Fernandes 391; q: Fernandes 187).

Figure 3. a-d. Acacia martiusiana. a. Leaflet. b. Leaf nectary. c. Inflorescence. d. Flower. e-g. Inga cylindrica. e. Leaf nectary. f. Flower. g. Fruit. h-k. Inga leptantha. h. Leaf. i. Leaf nectary. j. Flower. k. Fruit. 1-n. Inga sessilis. 1. Leaf nectary. m. Flower. n. Fruit. o-q. Inga striata. o. Leaf nectary. p. Flower. q. Fruit (a-d: Fernandes 324; e, f: Fernandes et al. 97; g: Fernandes 175; h-j: Fernandes 111; k: Fernandes 117; 1, m: Fernandes et al. 192; n: Fernandes 304; o, p: Fernandes 391; q: Fernandes 187). 
na Bahia (Lewis 1987). A espécie está bem representada tanto no entorno quanto no interior dos fragmentos. Floresceu de abril a julho, e frutificou de setembro a dezembro.

14. Piptadenia gonoacantha (Mart.) J.F. Macbr., Contr. Gray Herb. 59: 17. 1919 झAcacia gonoacantha Mart., Flora 20(2) Beibl.: 109. 1837. Figura $4 \mathrm{c}-\mathrm{e}$

Árvores 9-10 m alt.; ramos jovens glabrescentes, inermes, estrias lamelares no caule. Estípulas 2,5-3 mm compr., ovadas, tomentosas; pecíolo 1,6-2,4 cm compr., cilíndrico ou canaliculado, glabrescente; nectários foliares cupuliformes, subsésseis, no pecíolo e entre os últimos pares de pinas; raque 5,2-10 cm compr., cilíndrica ou canaliculada, glabrescente; pinas 7-14 pares, foliólulos 27-44 pares por pina, 3,5-8 $\times 0,8-1 \mathrm{~mm}$, lineares, subfalcados, ápice agudo, base oblíqua, faces adaxial e abaxial glabrescentes, nervura principal submarginal. Inflorescências espiciformes, axilares; pedúnculo 3-4 $\mathrm{mm}$ compr.; raque $6,5-8 \mathrm{~cm}$ compr., estriada, glabrescente; brácteas 2-3,5 × 0,8-2 mm, lanceoladas, pubescentes; bractéolas 0,5-1 ×0,3 mm, ovadas, pubescentes; flores sésseis a subsésseis; cálice 0,8-1 mm compr., pubescente; corola 19-21 mm compr., glabra; estames 3-4 mm compr., filetes brancos; gineceu estipitado; estípite 1,3-1,6 mm compr., glabro; ovário 0,8-1,1 mm compr., seríceo; estilete 1,8-2,5 mm compr., curvo, glabro; estigma terminal, diminuto, glabro. Legume 7-14 × 1,6-2,1 cm, reto, plano, margem reta, valvas cartáceas, glabrescente; 6-11 sementes, $8 \times 8 \mathrm{~mm}$, circulares, enegrecidas.

Material selecionado: BRASIL. Minas Gerais: Araponga, Fragmento da Lurdinha, 5-X-2005, fr., J.M. Fernandes et al. 75 (VIC).

Material adicional examinado: BRASIL. MINAS GeRAIS: Araponga, Comunidade dos Lanas, 16-XII-2006, fl., J.M. Fernandes 416 (VIC).

Piptadenia gonoacantha diferencia-se das outras espécies de Piptadenia que ocorrem na área de estudo, por apresentar hábito arbóreo e o caule com súber lamelar. Ocorre na Bolívia, Peru e Colômbia. No Brasil, está distribuída nos estados de Goiás, Bahia, Espírito Santo, Minas Gerais, Rio de Janeiro, São Paulo, Paraná, Santa Catarina e Mato Grosso do Sul (Oliveira Filho 2006). Nos fragmentos a espécie está bem representada, tanto no entorno quanto no interior da floresta. Frutificou de outubro a dezembro e floresceu em dezembro.
15. Piptadenia micracantha Benth., Trans. Linn. Soc. London 30(3): 369. 1875.

Figura 4f-i

Lianas; ramos jovens estriados, tomentosos, armados. Estípulas 2-4,5 $\mathrm{mm}$ compr., lineares tomentosas; pecíolo 2-4 cm compr., estriado, tomentoso, acúleos recurvos; raque 6,2-10 cm compr., estriada, tomentosa, aculeada; nectários foliares verruciformes, entre os últimos pares de pinas; pinas 11-17 pares, foliólulos 34-40 pares por pina, 2,5 $\times$ 0,6-1 mm, lineares a falcados, ápice acuminado, base oblíqua, faces adaxial e abaxial esparso-seríceas, nervura principal central. Inflorescências espiciformes, axilares, terminais; pedúnculo 0,5-1 mm compr.; raque $6,5-9 \mathrm{~cm}$ compr., cilíndrica, tomentosa; brácteas não observadas; bractéolas 1,5 × 0,2-0,4 mm, lanceoladas, pubescentes; flores sésseis; cálice 1-12 mm compr., glabrescente; corola $3 \mathrm{~mm}$ compr., glabra; estames 3,5-4,5 $\mathrm{mm}$ compr., filetes avermelhados; gineceu estipitado; estípite 1-1,2 mm compr., glabro; ovário 0,8-1 mm compr., seríceo; estilete 1,2 mm compr., glabro; estigma terminal, diminuto, glabro. Legume 6-13×2,2-2,7 cm, reto, plano compresso, margens sinuosas, valvas cartáceas, glabrescente; 3-8 sementes.

Material selecionado: BRASIL. Minas Gerais: Araponga, Fragmento da Lurdinha, 28-IV-2006, fl., J.M. Fernandes 274 (VIC); 5-VIII-2006, fr., J.M. Fernandes 326 (VIC).

É citada a ocorrência de Piptadenia micracantha para os Estados de Minas Gerais, Rio de Janeiro e São Paulo (Tamashiro 1989). No Fragmento da Lurdinha está pouco representada, apenas uma população no entorno. Floresceu de abril a maio, e frutificou de agosto a setembro.

Subfamília Papilionoideae

16. Andira surinamensis (Bondt) Splitg. ex Pulle, Enum. Vasc. Pl. Surinam 229. 1906 =Geoffroea surinamensis Bondt, Cort. Geoffr. Surinam. 12-16. 1788.

Figura $4 \mathrm{j}-\mathrm{n}$

Árvores 4-5 m alt.; ramos jovens esparsotomentosos. Estípulas 2-3 mm compr., falciformes, esparso-tomentosas, caducas; pecíolo 3-4 cm compr., cilíndrico a estriado, esparso-tomentoso; raque 4,5-9 cm compr., canaliculada, tomentosa; folíolos 7-9, 3-5,3 $\times 1,5-3,3 \mathrm{~cm}$, obovados, ápice retuso a emar- 
ginado, base aguda ou arredondada, face adaxial glabrescente, face abaxial serícea. Pedúnculo $1-2 \mathrm{~cm}$ compr.; raque 6-18 cm compr., cilíndrica, tomentosa; brácteas $2,5-3 \times 1 \mathrm{~mm}$, lanceoladas, tomentosas; bractéolas 1,5-2 $\times 0,5 \mathrm{~mm}$, lanceoladas, tomentosas; cálice $6 \mathrm{~mm}$ compr., tomentoso; corola púrpuroesbranquiçada, vexilo $11 \mathrm{~mm}$ compr., alas $11 \mathrm{~mm}$ compr., pétalas da carena $10 \mathrm{~mm}$ compr.; estames 8-9 mm compr.; gineceu estipitado; estípite 3,5-4 mm compr., ciliado; ovário 4-5 mm compr., glabro; estilete 3-3,5 mm compr., curvo, glabrescente; estigma terminal, cilíndrico, ciliado. Drupa $2-2,5 \mathrm{~cm}$ compr., ovóide, glabro; 1 semente, $1,8 \times 1,5 \mathrm{~cm}$, ovada, esbranquiçada.

Material selecionado: BRASIL. Minas Gerais: Araponga, Fragmento da Lurdinha, 5-IX-2005, fl., J.M. Fernandes \& Garcia 89 (VIC); 23-XI-2005, fr., J.M. Fernandes et al. 102 (VIC).

Andira surinamensis distingue-se das outras espécies de Papilionoideae que ocorrem na área de estudo por apresentar fruto do tipo drupa. Está distribuída na América Tropical, ocorrendo em Trinidad, Colômbia, Venezuela, Guianas, Suriname, Guiana Francesa, Equador, Peru, Bolívia e Brasil, onde ocorre nos Estados do Ceará, Maranhão, Mato Grosso, Pará, Roraima, Amazonas (Pennington 2003), Minas Gerais (Mattos 1979a), e na Bahia (Lewis 1987). No Fragmento da Lurdinha ocorrem apenas em áreas do entorno. Floresceu de setembro a dezembro e frutificou de dezembro a março.

Dalbergia L. f., Suppl. Pl. 52, 316. 1781 [1782].

Árvores, arbustos ou lianas. Folhas pinadas, imparipinadas; estípulas decíduas, estipelas ausentes; folíolos alternos. Inflorescências paniculadas, axilares ou terminais; flores pentâmeras, zigomorfas; cálice gamossépalo, campanulado; corola dialipétala, branca, creme, amarela ou violácea; androceu monadelfo, diadelfo ou triadelfo, estames 9 ou 10, heterodínamos, anteras isomórficas; gineceu unicarpelar, ovário estipitado, uni a triovulado. Fruto legume samaróide ou sâmara, com região seminífera central; sementes de 1-3, reniformes, compressas.

17. Dalbergia foliolosa Benth., J. Linn. Soc., Bot. 4(Suppl.): 37. 1860.

Figura 4o-r

Árvores 3-6 m alt.; ramos esparso-seríceos. Estípulas 1,1-3 mm compr., triangulares, seríceas; pecíolo 1-2 cm compr., cilíndrico, seríceo; raque 4-7,2 cm compr., cilíndrica, serícea; 9-18 folíolos, 1,2-4 $\times 0,5-1,2 \mathrm{~cm}$, ovado-oblongos, ápice agudo ou retuso, base obtusa, faces adaxial e abaxial seríceas. Inflorescências paniculadas, escorpióides, axilares ou terminais; pedúnculo 0,8-4 cm compr.; brácteas $1,4 \times 0,8 \mathrm{~mm}$, oblongas, tomentosas; bractéolas $1 \times$ 0,3-0,5 mm, ovadas, tomentosas; cálice 4-4,5 mm compr., tomentoso externamente; corola creme, vexilo 6-6,5 mm compr., alas 6-7 mm compr., pétalas da carena $6 \mathrm{~mm}$ compr.; estames 9 , monadelfos, $6-7 \mathrm{~mm}$ compr.; gineceu estipitado; estípite $2 \mathrm{~mm}$ compr., glabro; ovário 3-3,5 mm compr., seríceo; estilete $1,5 \mathrm{~mm}$ compr., curvo, glabro; estigma terminal, cilíndrico, glabro. Legume samaróide 2,5-7,6 $\times$ 1,4-1,8 cm, elíptico-oblongo, glabrescente; $1-2$ sementes, $6 \times 4 \mathrm{~mm}$ compr., reniformes, acinzentadas.

Material selecionado: BRASIL. Minas Gerais: Araponga, Fragmento da Eva, 14-II-2006, fl., J.M. Fernandes 177 (VIC); 5-VIII-2006, fr., J.M. Fernandes 236 (VIC).

Dalbergia foliolosa distingue-se de Dalbergia nigra por apresentar folíolos ovado-oblongos, ovário seríceo e legume samaróide elíptico-oblongo, enquanto que $D$. nigra, possui folíolos oblongo-elípticos, ovário ciliado nas margens e legume samaróide elíptico. Ocorre nos Estados da Bahia, Minas Gerais, São Paulo e na região central do Brasil, em ambientes desde o nível do mar até 1.000 metros de altitude, principalmente em floresta atlântica, cerrado e restinga (Carvalho 1997). Está bem representada nos fragmentos estudados, ocorrendo tanto no entorno quanto no interior da floresta. Floresceu de fevereiro a maio, e frutificou de junho a outubro.

18. Dalbergia frutescens (Vell.) Britton var. frutescens, Bull. Torrey Bot. Club 16(12): 324.1889 $\equiv$ Pterocarpus frutescens Vell., Fl. Flumin., 302. 1829.

Figura 4s-u

Lianas, raramente arbustos escandentes; ramos jovens esparso-pilosos, lenticelados. Estípulas 3-5 mm compr., obovadas, ferrugíneo-tomentosas; pecíolo 1,8-3,7 cm compr., cilíndrico, esparso-tomentoso; raque 8-14 cm compr., cilíndrica, esparso-tomentosa; 9-12 folíolos, 2,4-5,7 × 1,6-2,9 cm, ovados a elípticos, ápice retuso ou agudo, base obtusa, face adaxial glabra, face abaxial serícea. Inflorescências paniculadas, axilares; pedúnculo 1,8-3 cm compr.; brácteas 0,8-1 ×0,5 mm, 


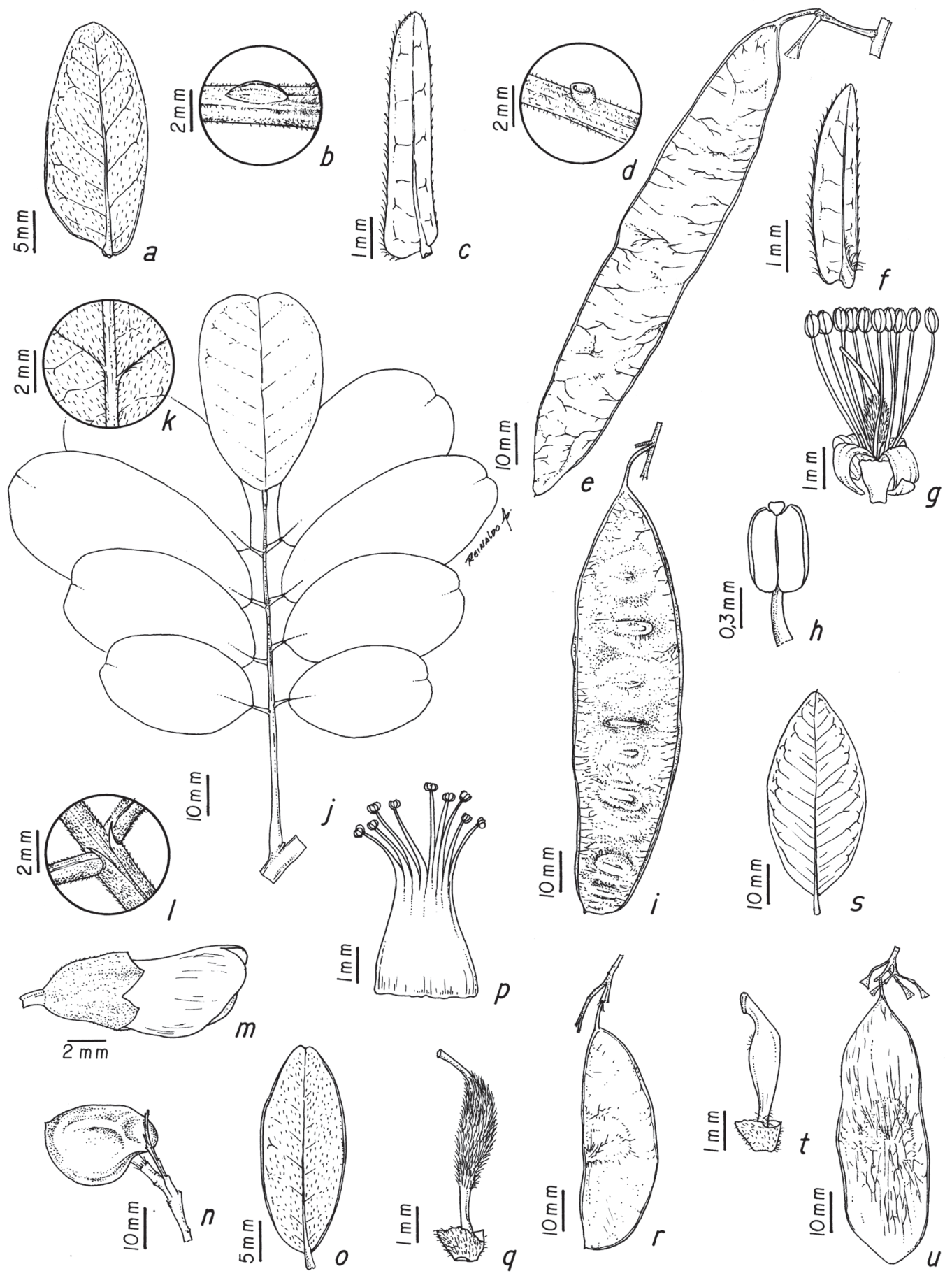

Figura 4. a-b. Piptadenia adiantoides. a. Foliólulo. b. Nectário foliar. c-e. Piptadenia gonoacantha. c. Foliólulo. d. Nectário foliar. e. Fruto. f-i. Piptadenia micracantha. f. Foliólulo. g. Flor. h. Estame. i. Fruto. j-n. Andira surinamensis. j. Folha. k. Indumento da face abaxial do folíolo. l. Estipelas. m. Flor. n. Fruto. o-r. Dalbergia foliolosa. o. Folíolo. p. Androceu. q. Gineceu. r. Fruto. s-u. Dalbergia frutescens var. frutescens. s. Folíolo. t. Gineceu. u. Fruto (a, b: Fernandes 273; c-e: Fernandes et al. 75; f: Fernandes 350; g, h: Fernandes 274; i: Fernandes 350; j-n: Fernandes \& Garcia 89; o-q: Fernandes 178; r: Fernandes 236; s, t: Fernandes \& Garcia 101; u: Fernandes 185). Figure 4. a-b. Piptadenia adiantoides. a. Leaflets. b. Leaf nectary. c-e. Piptadenia gonoacantha. c. Leaflets. d. Leaf nectary. e. Fruit. f-i. Piptadenia micracantha. f. Leaflets. g. Flower. h. Stamen. i. Fruit. j-n. Andira surinamensis. j. Leaf. k. Indument of abaxial leaflet surface. 1. Stipels. m. Flower. n. Fruit. o-r. Dalbergia foliolosa. o. Leaflet. p. Androecium. q. Gynoecium. r. Fruit. s-u. Dalbergia frutescens var. frutescens. s. Foliole. t. Gynoecium. u. Fruit (a, b: Fernandes 273; c-e: Fernandes et al. 75; f: Fernandes 350; g, h: Fernandes 274; i: Fernandes 350; j-n: Fernandes \& Garcia 89; o-q: Fernandes 178; r: Fernandes 236; s, t: Fernandes \& Garcia 101; u: Fernandes 185). 
triangulares, esparso-tomentosas; bractéolas $0,8 \times$ 0,5 mm, ovadas, esparso-tomentosas; cálice 2,5-3 mm compr., esparso-tomentoso externamente; corola creme, vexilo 3,4-3,5 mm compr., alas 3,5-3,6 mm compr., pétalas da carena 3,6-4 mm compr.; estames 10, nonadelfos, 2,5-2,8 mm compr.; gineceu estipitado, estípite 1,3-1,5 mm compr., glabrescente; ovário 1,4-1,7 mm compr., ciliado; estilete $0,5 \mathrm{~mm}$ compr., reto, glabro; estigma truncado, glabro, terminal. Sâmara 5,2-7 × 1,8-2,2 cm, elíptica ou oblonga, glabra; 1 semente, $1,3 \times 0,7 \mathrm{~cm}$, reniforme, acinzentada.

Material selecionado: BRASIL. Minas Gerais: Araponga, Fragmento da Lurdinha, 23-XI-2005, fl., J.M. Fernandes \& Garcia 101 (VIC); 25-II-2006, fr., J.M. Fernandes 185 (VIC).

Dalbergia frutescens var. frutescens distingue-se das outras espécies de Dalbergia da área estudada por ser uma liana e apresentar sempre uma semente. Ocorre na Argentina, Brasil, Guiana, Paraguai e Venezuela (Carvalho 1997). No Brasil, habita regiões de floresta atlântica, restinga, floresta de altitude e mata de galeria em domínio de cerrado, desde o nível do mar até vegetações situadas a 1.200 metros de altitude (Carvalho 1997). Nos fragmentos ocorre em áreas abertas, geralmente com porte menor (arbustos escandentes) em relação aos indivíduos encontrados no interior da floresta, que são lianas. Floresceu de novembro a março e frutificou de abril a outubro.

19. Dalbergia nigra (Vell.) Allemão ex Benth., J. Linn. Soc., Bot. 4(Suppl.): 36. $1860 \equiv$ Pterocarpus niger Vell., Fl. Flumin.: 300. 1829.

Figura 5a-d

Árvore ca. $12 \mathrm{~m}$ alt.; ramos jovens esparsotomentosos. Estípulas 3-3,5 mm compr., lanceoladas, glabrescentes; pecíolo 0,5-1,1 cm compr., cilíndrico, esparso-tomentoso; raque 4,5-7,5 cm compr., canaliculada, esparso-tomentosa; 11-23 folíolos, 0,6-1,7 ×0,3-0,7 cm, oblongo-elípticos, ápice retuso, base arredondada, face adaxial glabra ou glabrescente, face abaxial esparso-serícea. Inflorescências paniculadas, axilares; pedúnculo 3-6 mm compr.; raque 0,7-1,5 cm compr., serícea, canaliculada; cálice 3-4 mm compr.; corola amarela esverdeada, vexilo $8 \mathrm{~mm}$ compr., alas 7-8 mm compr., pétalas da carena 5-6 $\mathrm{mm}$ compr.; estames 10 , raramente 9, monadelfos, 4-5 mm compr.; gineceu estipitado; estípite 2,3-2,5 mm compr., glabro; ovário 2 mm compr., ciliado; estilete 1,3-1,5 mm compr., glabro; estigma cilíndrico, glabro, terminal. Legume samaróide 4,1-4,5 × 0,9-1,2 cm, elíptico, glabro ou glabrescente; 1-2 sementes, $9 \times 5 \mathrm{~mm}$, reniformes, glabras, avermelhadas.

Material selecionado: BRASIL. Minas Gerais: Araponga, Fragmento da Eva, 12-IX-2006, fr., J.M. Fernandes 378 (VIC).

Material adicional examinado: BRASIL. MinAS GeRAIS: Canaã, perímetro urbano, 15-XI-2005, fl., J.M. Fernandes 395 (VIC).

Dalbergia nigra ocorre do Sul da Bahia até o Norte do Espírito Santo, de Minas Gerais até o Norte de São Paulo (Carvalho 1997). No Fragmento da Eva foi encontrado um indivíduo adulto no entorno. Foi coletada com flor em novembro e frutificou em setembro.

20. Hymenolobium janeirense var. stipulatum (N.F. Mattos) Lima, Bradea, BPH /S 3(45): 404.1983 $\equiv$ Hymenolobium stipulatum $\mathrm{N}$. Mattos, Loefgrenia 70: 2. 1976.

Figura 5e-f

Árvores 10-12 m alt.; ramos jovens ferrugíneotomentosos. Estípulas 6-8 mm compr., linearlanceoladas, tomentosas; folhas pinadas, imparipinadas; pecíolo 3-4 cm compr., cilíndrico, tomentoso; 29-35 folíolos, 2-6,5×1-1,6 cm, elíptico-oblongos, ápice arredondado, base arredondada, faces adaxial e abaxial vilosas. Inflorescências paniculadas, terminais; pedúnculo 2-3,5 cm compr.; brácteas $2 \times 1 \mathrm{~mm}$, triangulares, tomentosas; bractéolas caducas; flores subsésseis, zigomorfas, pentâmeras; cálice $7 \mathrm{~mm}$ compr., gamossépalo, campanulado, tomentoso externamente; corola dialipétala, vexilo $13 \mathrm{~mm}$ compr., glabrescente externamente, alas $9 \mathrm{~mm}$ compr., pétalas da carena $11 \mathrm{~mm}$ compr.; 10 estames, 9-11 mm compr., monadelfos, heterodínamos, anteras isomórficas; gineceu estipitado; estípite $3 \mathrm{~mm}$ compr., glabro; ovário 6-7 mm compr., uniovulado, ciliado; estilete $3 \mathrm{~mm}$ compr., curvo, glabro; estigma capitado, glabro, terminal. Sâmara 6-6,5 × 1,6-1,7 cm, lanceolada, plana, glabra; 1 semente, 2,2 $2 \times 0,4 \mathrm{~cm}$, elipsóide, enegrecida.

Material selecionado: BRASIL. Minas Gerais: Araponga, Fragmento da Eva, 18-IX-2006, fl., J.M. Fernandes 386 (VIC); 16-XII-2006, fr., J.M. Fernandes 396 (VIC).

Hymenolobium stipulatum var. stipulatum é reconhecida na área estudada por apresentar estípulas com cerca de 6-8 mm compr., folíolos acima de 29 , 
elíptico-oblongos e sâmara lanceolada-linear, com nervuras submarginais. Há registros de sua ocorrência nos Estados da Bahia (Lewis 1987) e Minas Gerais (Mattos 1979b), ocorrendo em capoeira, margem de estradas e matas alagadas (Lewis 1987). No Fragmento da Eva a espécie está pouco representada, provavelmente devido à importância econômica da madeira na região, conhecida como angelim. Floresceu em outubro e frutificou em dezembro.

Machaerium Pers., Syn. Pl. 2(2): 276. 1807.

Árvores, arbustos ou lianas. Folhas pinadas, imparipinadas; estípulas decíduas, estipelas ausentes; folíolos 5-23, alternos ou opostos. Inflorescências racemosas, paniculadas, axilares ou terminais; flores pentâmeras, zigomorfas; cálice gamossépalo, campanulado; corola dialipétala, papilionada, branca, creme, lilás ou vinácea; androceu monadelfo ou parcialmente diadelfo, 10 estames, heterodínamos, anteras isomórficas; gineceu unicarpelar, ovário estipitado, uniovulado. Fruto sâmara, núcleo seminífero basal, asas oblongas, subfalcadas ou geniculadas; semente 1 , oblonga ou reniforme.

21. Machaerium acutifolium Vogel, Linnaea 11: 187. 1837.

Figura 5g-i

Árvores $3 \mathrm{~m}$ alt., raramente lianas; ramos jovens glabrescentes, acúleos recurvos. Estípulas 4-4,5 mm compr., lanceoladas, vilosas; pecíolo 1,4-3,5 cm compr., cilíndrico, glabrescente; raque 7,7-19 cm compr., esparso-tomentosa; 12-17 folíolos, 3,5-7,5 × 1,3-2,8 cm, oval-lanceolados a elípticos, ápice agudo a acuminado, base arredondada, raro acunheada, faces adaxial e abaxial esparso-seríceas. Inflorescências paniculadas, axilares, terminais; pedúnculo $5 \mathrm{~mm}$ compr.; brácteas $2 \mathrm{~mm}$ compr., ovadas, tomentosas; cálice 2,6-3 mm compr., tomentoso; corola lilás, vexilo $8-9 \mathrm{~mm}$ compr., tomentoso externamente, alas 7-8 mm compr.; pétalas da carena 7-8,5 mm compr.; estames monadelfos, 5-6 mm compr.; estípite 2,5-4 mm compr., seríceo; ovário 3-4 mm compr., tomentoso; estilete 1,1-1,5 mm compr., curvo, glabro; estigma cilíndrico, glabro, terminal. Sâmara 5,5-7,5 × 1,4-1,8 cm, oblongas, asa reticulada, região seminífera enrugada, glabrescente; semente $1,4 \times 0,5-0,6 \mathrm{~cm}$, oblonga, enegrecida.

Material selecionado: BRASIL. Minas Gerais: Araponga, Fragmento da Lurdinha, 25-II-2006, fl., J.M. Fernandes 191 (VIC); 28-IV-2006, fr., J.M.

\section{Fernandes 279 (VIC).}

Dentre as espécies de Machaerium, pode ser reconhecida por apresentar folíolos oval-lanceolados e sâmara oblonga com região seminífera enrugada. Está distribuída na Argentina, Brasil, Bolívia, Paraguai e Venezuela (ILDIS 2008). No Brasil ocorre nos estados de São Paulo, Goiás, Mato Grosso, Minas Gerais (Sartori \& Tozzi 1998), e Bahia (ILDIS 2008). Nos fragmentos ocorre em áreas do entorno e interior da vegetação. Floresceu de fevereiro a março e frutificou de maio a setembro.

\section{Machaerium brasiliense Vogel, Linnaea 11: 185.} 1837.

Figura 5j-1

Árvores 7-8 m alt.; ramos jovens esparsotomentosos, inermes. Estípulas 1,5-2 cm compr., foliáceas, tomentosas; pecíolo 1,4-2,2 cm compr., cilíndrico, tomentoso; raque $6,1-7,3 \mathrm{~cm}$ compr., cilíndrica, ferrugíneo-tomentosa; 8-13 folíolos, 2-5,8× 1,2-2 cm, elípticos ou obovados, ápice acuminado a agudo, base arredondada, faces adaxial e abaxial esparso-tomentosas. Inflorescências paniculadas, axilares; pedúnculo 1,6-3,2 cm compr.; raque 2,5-4,3 cm compr., estriada, tomentosa; brácteas caducas; bractéolas 16-23 × 3-5 mm, lanceoladas, seríceas; flores pediceladas; cálice 3,5-4,5 mm compr., tomentoso externamente; vexilo 7-8,5 mm compr., glabrescente externamente, alas 7-7,5 mm compr.; pétalas da carena 7,6-8 mm compr.; estames diadelfos 9+1, 5,2-6_mm compr.; estípite 2,5 mm compr, glabro; ovário 2,6-3 mm compr., tomentoso; estilete 2,5-3,3 mm compr., curvo, glabro; estigma cilíndrico, glabro, terminal. Sâmara 5,5-7,5 × 1,4-1,8 cm, falciforme, asa oblonga, reticulada; semente $14-16 \mathrm{~mm}$ compr., reniforme, enegrecida.

Material selecionado: BRASIL. Minas Gerais: Araponga, Fragmento da Eva, 21-IX-2005, fr., J.M. Fernandes et al. 50 (VIC); 16-XII-2006, fl., J.M. Fernandes 398 (VIC).

Machaerium brasiliense assemelha-se a M. triste, da qual se diferencia pelas flores pediceladas e pelo hábito arbóreo, enquanto $M$. triste possui flores curto-pediceladas e hábito escandente. Ocorre nos estados de São Paulo, Minas Gerais, Mato Grosso, Paraná, Rio de Janeiro (Sartori \& Tozzi 1998), e Bahia (Lewis 1987). Nos fragmentos a espécie é muito comum. Floresceu em dezembro e frutificou de maio a novembro. 
23. Machaerium nyctitans (Vell.) Benth., Comm. Legum. Gen. 34. 1837 =Nissolia nyctitans Vell., Fl. Flumin. 7: 75. 1760.

Figura 5m-n

Árvores 10-12 m alt.; ramos jovens tomentosos a esparso-tomentosos, inermes. Estípulas 2-3 mm compr., ovadas, tomentosas; pecíolo 1,2-2,2 cm compr., cilíndrico, tomentoso; raque 8,5-14,5 cm compr., cilíndrica, tomentosa; 19-23 folíolos, 0,9-3,5 $\times$ 0,4-1,4 cm, oblongos, ápice retuso, base arredondada, face adaxial serícea, face abaxial esparso-tomentosa. Inflorescências paniculadas; pedúnculo 3-5 mm compr.; raque 1,1-3,2 cm compr., estriada, tomentosa; brácteas 1-2 mm compr., ovadas, tomentosas; bractéolas 3,3-4,2 mm compr., lanceoladas, tomentosas; flores subsésseis; cálice 5-6 mm compr., tomentoso externamente; corola vinácea, vexilo $8,5-10 \mathrm{~mm}$ compr., alas 8-10 mm compr., pétalas da carena $8 \mathrm{~mm}$ compr.; estames monadelfos, 5-9 mm compr.; estípite 3-4 mm compr., seríceo; ovário 3-4 mm compr., tomentoso; estilete 1,8-2 mm compr., curvo, glabro; estigma cilíndrico, glabro, terminal. Sâmara 4,5-6 × 1,5-1,7 cm, oblonga, pubescente, asa oblonga com nervuras longitudinais evidentes; semente 1,1-1,3 ×0,4-0,5 cm, reniforme, puberulenta, acinzentada.

Material selecionado: BRASIL. Minas Gerais: Araponga, Fragmento da Eva, 28-IV-2006, fl., J.M. Fernandes et al. 272 (VIC); 5-VIII-2006, fr., J.M. Fernandes et al. 342 (VIC).

Machaerium nyctitans difere-se das outras espécies ocorrentes na área estudada, por apresentar raque foliar densamente ferrugíneo-tomentosa, 19-23 folíolos, oblongos, e pelas sâmaras providas de nervuras longitudinais evidentes na asa. No Brasil, ocorre nos estados do Paraná, Rio de Janeiro, São Paulo, Minas Gerais e Bahia, sendo também citado para a Argentina (Mendonça-Filho et al. 2002). Nos fragmentos está bem representada tanto no interior quanto no entorno. Floresceu de fevereiro a maio e frutificou de agosto a novembro.

24. Machaerium triste Vogel, Linnaea 9: 416. 1837. Figura 5o-p

Lianas; ramos jovens esparso-tomentosos, inermes. Estípulas ca. $1 \mathrm{~mm}$ compr., ovada, esparso-tomentosa, caduca; pecíolo 1,6-2,6 cm compr., cilíndrico, esparsotomentoso; raque 4,5-6,7 cm compr., cilíndrica a estriada, esparso-tomentosa; 7-12 folíolos, 1,9-4,5 × 1-2,1 cm, elípticos ou obovados, ápice acuminado, base arredondada ou aguda, faces adaxial e abaxial glabrescentes. Flores não observadas. Sâmara 6-6,5 × 1,5-1,8 cm, falciforme, glabrescente, asa brilhante; semente 1,2-1,4×0,7 cm, reniforme, enegrecida.

Material selecionado: BRASIL. Minas Gerais: Araponga, Fragmento da Lurdinha, 26-III-2006, fr., J.M. Fernandes 242 (VIC).

Sartori \& Tozzi (1998) citaram a ocorrência da espécie para os estados de São Paulo e Paraná, distribuída em ambientes de mata mesófila semidecidual montana. No Fragmento da Lurdinha ocorre no entorno e interior. A floração não foi observada, mas frutificou entre março e maio.

25. Machaerium uncinatum (Vell.) Benth., Comm. Legum. Gen.: 34. 1837 三Nissolia uncinata Vell., Fl. Flumin. 295; 7: pl. 76. 1825.

Figura 5q-r

Lianas; ramos jovens pubescentes, acúleos recurvos, raro retos. Estípulas não observadas; pecíolo 0,9-1,6 cm compr., estriado, pubescente; raque 4,5-9 cm compr., estriada, pubescente; 23-35 folíolos, 1-1,9 × 0,4-0,6 cm, oblongos, ápice obtuso ou retuso, base aguda, face adaxial glabra, face abaxial serícea a esparso-serícea. Flores não observadas. Sâmara 4,1-4,5 × 0,9-1 cm, falciforme, glabrescente, região seminífera geniculada, asa reticulada; semente $1 \times$ $0,4 \mathrm{~cm}$, reniforme, avermelhada.

Material selecionado: BRASIL. Minas Gerais: Araponga, Fragmento da Lurdinha, 5-VIII-2006, fr., J.M. Fernandes 340 (VIC).

Machaerium uncinatum diferencia-se das outras espécies de Machaerium existentes na área de estudo, pelo hábito escandente e sâmara geniculada. Está distribuída em São Paulo, Rio de Janeiro, Espírito Santo, Paraná (Sartori \& Tozzi, 1998), Bahia (Lewis 1987) e Minas Gerais. Ocorre em vegetação de restinga, mata ciliar, clareiras e bordas de matas secundárias (Sartori \& Tozzi 1998). No Fragmento da Lurdinha ocorre no subosque e no entorno. A floração não foi observada, mas frutificou de agosto a novembro.

26. Swartzia pilulifera Benth., J. Bot. (Hooker) 2(10): 90. 1840.

Figura 5t-x

Árvores 4-5 m alt.; ramos jovens ferrugíneotomentosos. Estípulas $3,1 \times 1 \mathrm{~mm}$, lanceoladas, tomentosas, estipelas caducas; folha pinada, imparipinada; pecíolo 7-12 mm compr., cilíndrico, 


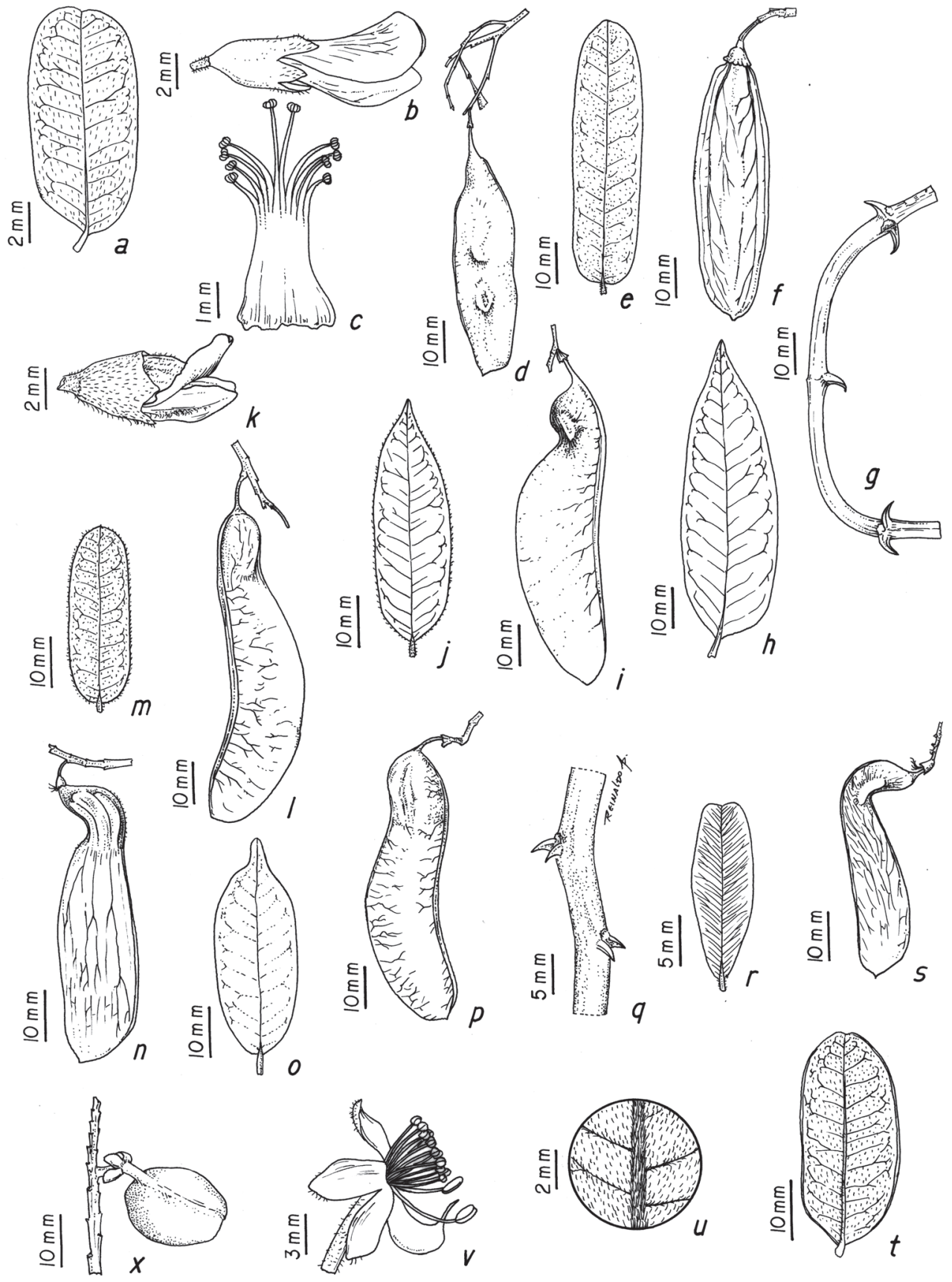

Figura 5. a-d. Dalbergia nigra. a. Folíolo. b. Flor. c. Androceu. d. Fruto. e-f. Hymenolobium janeirense var. stipulatum. e. Folíolo. f. Fruto. g-i. Machaerium acutifolium. g. Ramo jovem com acúleos. h. Folíolo. i. Fruto. j-1. Machaerium brasiliense. j. Folíolo. k. Flor. 1. Fruto. m-n. Machaerium nyctitans. m. Folíolo. n. Fruto. o-p. Machaerium triste. o. Folíolo. p. Fruto. q-s. Machaerium uncinatum. q. Ramo jovem com acúleos. r. Folíolo. s. Fruto. t-x. Swartzia pilulifera. t. Folíolo. u. Indumento da face abaxial do folíolo. v. Flor. x. Fruto (a-d: Fernandes 395; e, f: Fernandes 396; g-i: Fernandes 279; j: Fernandes et al. 50; k: Fernandes 398; 1: Fernandes et al. 50; m: Fernandes et al. 272; n: Fernandes et al. 342; o, p: Fernandes 242; q-s: Fernandes 340; t, u: Fernandes et al. 99; v: Fernandes 411; $\mathrm{x}$ : Lima \& Ferreira 291).

Figure 5. a-d. Dalbergia nigra. a. Leaflet. b. Flower. c. Androecium. d. Fruit. e-f. Hymenolobium janeirense var. stipulatum. e. Leaflet. f. Fruit. g-i. Machaerium acutifolium. g. Young branch with thorns. h. Leaflet. i. Fruit. j-1. Machaerium brasiliense. j. Leaflet. k. Flower. 1. Fruit. m-n. Machaerium nyctitans. m. Leaflet. n. Fruit. o-p. Machaerium triste. o. Leaflet. p. Fruit. q-s. Machaerium uncinatum. q. Young branch with thorns. r. Leaflet. s. Fruit. t-x. Swartzia pilulifera. t. Leaflet. u. Indument of abaxial leaflet surface. v. Flower. x. Fruit (a-d: Fernandes 395; e, f: Fernandes 396; g-i: Fernandes 279; j: Fernandes et al. 50; k: Fernandes 398; 1: Fernandes et al. 50; m: Fernandes et al. 272; n: Fernandes et al. 342; o, p: Fernandes 242; q-s: Fernandes 340; t, u: Fernandes et al. 99; v: Fernandes 411; $\mathrm{x}$ : Lima \& Ferreira 291). 
tomentoso; raque foliar 1,7-3,5 $\mathrm{cm}$ compr., canaliculada, tomentosa; 5-7 folíolos, 1,1-4,5 $\times$ 0,8-1,7 cm, opostos, elípticos ou obovados, ápice agudo a levemente retuso, base obtusa, face adaxial glabra, face abaxial serícea. Inflorescências racemosas, axilares; pedúnculo 6-10 $\mathrm{mm}$ compr.; raque 2,3-3,5 $\mathrm{cm}$, estriada, tomentosa; brácteas 1-1,2 mm compr., lanceoladas, tomentosas; cálice 3-4 segmentos, 4-5,5 mm compr., tomentoso externamente; corola ausente; androceu heterodínamo, estames maiores 2-3, 3-3,5 mm compr., menores 12-24, 8-12 mm compr., anteras isomórficas; gineceu estipitado; estípite 2-3 mm compr., tomentoso; ovário 3-5 mm compr., densamente tomentoso; estilete $5-10 \mathrm{~mm}$ compr., indumento; estigma diminuto, glabro, terminal. Legume 2-2,4 $\times$ 1,5-1,6, elíptico, deiscente; 1 semente, $15 \times 8 \mathrm{~mm}$, obovada, preta, arilo branco.

Material selecionado: BRASIL. Minas Gerais: Araponga, Fragmento da Eva, 16-XII-2006, fl., J.M. Fernandes 411 (VIC).

Material adicional examinado: BRASIL. MinAs GeRAIS: Ouro Preto, Trilha Alcan, Parque Estadual do Itacolomi, 16-II-2005, fr., L.C.P. Lima \& S.C. Ferreira 291 (VIC).

Swartzia pilulifera é reconhecida na área de estudo por apresentar flores apétalas, frutos do tipo legume, com apenas uma semente envolta por arilo branco. Está distribuída em Minas Gerais, Rio de Janeiro, São Paulo, Paraná a Santa Catarina, ocorrendo em florestas ombrófilas de altitude e semideciduais (Cowan 1967, Mansano \& Lima 2007). Nos fragmentos está bem representada, principalmente no entorno. Floresceu de novembro a dezembro, mas não foi observada a formação de frutos.

\section{Agradecimentos}

Ao CNPq, pela bolsa concedida ao primeiro autor; à FAPEMIG e ao Centro de Tecnologias Alternativas da Zona da Mata Mineira (CTA/ZM), pelo apoio financeiro e técnico oferecido durante a realização da pesquisa; ao ilustrador botânico Reinaldo Pinto; aos colegas de campo Rafael e Osvaldo.

\section{Literatura citada}

Barneby, R.C. \& Grimes, J.W. 1996. Silk tree, Guanacast, Monkey's Earring: A generic system for the Synandrous Mimosaceae of the Americas. Memoirs of the New York Botanical Garden 74: 1-292.
Barroso, G.M., Morim, M.P., Peixoto, A.L. \& Ichasso, C.L.F. 1999. Frutos e sementes: morfologia aplicada à sistemática de dicotiledôneas. Viçosa - MG: Imprensa Universitária.

Bortoluzzi, R.L.C., Carvalho-Okano, R.M., Garcia, F.C.P. \& Tozzi, A.M.G.A. 2004. Leguminosae, Papilionoideae no Parque Estadual do Rio Doce, Minas Gerais, Brasil II: árvores e arbustos escandentes. Acta Botanica Brasilica 18: 49-71.

Bortoluzzi, R.L.C., Garcia, F.C.P., Carvalho- Okano, R.M. \& Tozzi, A.M.G.A. 2003. Leguminosae-Papilionoideae no Parque Estadual do Rio Doce, Minas Gerais, Brasil. I: trepadeiras e subarbustos. Iheringia, série Botânica 58: $25-60$

Burkart, A. 1979. Leguminosas - Mimosoideas. In: R. Reitz (ed.) Flora Ilustrada Catarinense. Herbário Barbosa Rodrigues, Itajaí.

Carvalho, A.M. 1997. A synopsis of the genus Dalbergia (Fabaceae: Dalbergieae) in Brazil. Brittonia 49: 87-109.

Chappil, J.A. 1995. Cladistic analysis of the Leguminosae: the development of an explicit phylogenetic hypothesis. In: M. Crisp \& J.J. Doyle (eds.). Advances in Legume Systematic 7: Phylogeny. Royal Botanic Gardens, Kew, pp.1-9.

Cowan, R.S. 1967. Swartzia (Leguminosae, Caesalpinioideae, Swatzieae). Flora Neotropica Monograph 1: 1-228.

Drummond, G.M., Martins, C.S., Machado,A.B.M., Sebaio, F.A. \& Antonini, Y. 2005. Biodiversidade em Minas Gerais: um atlas para sua conservação. 2 ed. Fundação Biodiversitas, Belo Horizonte.

Dwyer, J.D. 1954. The Tropical American genus Tachigalia Aubl. (Caesalpiniaceae). Annals of the Missouri Botanical Garden 41: 223-261.

Dwyer, J.D. 1957. The Tropical American genus Sclerolobium Vogel (Caesalpiniaceae). Lloydia 20: 67-119.

Fidalgo, O. \& Bononi, V.L.R. 1989. Técnicas de coleta, preservação e herborização do material botânico. Instituto de Botânica, São Paulo.

Filardi, F.L.R., Garcia, F.C.P. \& Carvalho-Okano, R.M. 2007. Espécies lenhosas de Papilionoideae (Leguminosae) na Estação Ambiental de Volta Grande, Minas Gerais, Brasil. Rodriguésia 58: 363-378.

Forzza, R.C., Leitman, P.M., Costa,A.F., Carvalho Jr.,A.A., Peixoto, A.L., Walter, B.M.T., Bicudo, C., Zappi, D., Costa, D.P., Lleras, E., Martinelli, G., Lima, H.C., Prado, J., Stehmann, J.R., Baumgratz, J.F.A., Pirani, J.R., Sylvestre, L., Maia, L.C., Lohmann, L.G., Queiroz, L.P., Silveira, M., Coelho, M.N., Mamede, M.C., Bastos, M.N.C., Morim, M.P., Barbosa, M.R., Menezes, M., Hopkins, M., Secco, R., Cavalcanti, T.B. \& Souza, V.C. 2010. Introdução. in Lista de Espécies da Flora do Brasil. Jardim Botânico do Rio de Janeiro, Rio de Janeiro. 
Garcia, F.C.P. 1998. Relações sistemáticas e fitogeografia do gênero Inga Miller (Leguminosae, Mimosoideae, Ingeae) nas florestas da costa sul e sudeste do Brasil. Tese de Doutorado, Universidade Estadual Paulista, Rio Claro.

Garcia, F.C.P. \& Fernandes, J.M. 2010. Inga in Lista de Espécies da Flora do Brasil. Jardim Botânico do Rio de Janeiro. (http://floradobrasil.jbrj.gov.br/2010/FB022803).

Golfari, L. 1975. Zoneamento Ecológico do Estado de Minas Gerais para reflorestamento. Série técnica 3. CPFRC, Belo Horizonte.

Guedes-Bruni, R.R., Morim, M.P., Lima, H.C. \& Sylvestre, L.S. 2002. Inventário florístico. In: L.S. Sylvestre \& M.M.T. Rosa (eds.). Manual metodológico para estudos botânicos na Mata Atlântica. Rio de Janeiro: Seropédica, pp. 24-49.

ILDIS. 2008. International legume database \& information service. http://www.ildis.org (acesso em 3.09.2008).

Irwin, H.S. \& Barneby, R.C. 1982. The American Cassinae, a synoptical revision of Leguminosae, Tribe Cassieae, subtribe Cassinae in the New World. Memoirs of the New York Botanical Garden 35:1-918.

Lewis, G. 1987. Legumes of Bahia. Royal Botanic Gardens, Kew.

Lewis, G., Schrine, B., Mackinder, B. \& Lock, M. 2005. Legumes of the world. Royal Botanic Gardens, Kew.

Lima, L.C.P., Garcia, F.C.P. \& Sartori, A.L.B. 2007. Leguminosae nas florestas estacionais do Parque Estadual do Itacolomi, Minas Gerais, Brasil: ervas, arbustos, subarbustos, lianas e trepadeiras. Rodriguésia 58: 331-358.

Lima, H.C., Queiroz, L.P., Morim, M.P., Souza, V.C., Dutra, V.F., Bortoluzzi, R.L.C., Iganci, J.R.V., Fortunato, R.H., Vaz,A.M.S.F., Souza, E.R., Filardi, F.L.R., Valls, J.F.M., Garcia,F.C.P., Fernandes, J.M., Martins-da-Silva, R.C.V., Perez, A.P.F., Mansano, V.F., Miotto, S.T.S., Tozzi, A.M.G.A., Meireles, J.E., Lima, L.C.P., Oliveira, M.L.A.A., Flores, A.S., Torke, B.M., Pinto, R.B., Lewis, G.P., Barros, M.J.F., Ribeiro, R.D., Schütz, R., Pennington, T., Klitgaard, B.B., Rando, J.G., Scalon, V.R., Cardoso, D.B.O.S., Costa, L.C., Silva, M.J., Moura, T.M., Barros, L.A.V., Silva, M.C.R., Queiroz, R.T., Sartori, A.L.B.\& Camargo, R. 2010. Fabaceae in Lista de Espécies da Flora do Brasil. Jardim Botânico do Rio de Janeiro. (http://floradobrasil.jbrj.gov.br/2010/FB000115).

Mansano, V.F. \& Lima, J.R. 2007. O gênero Swartzia Schreb. (Leguminosae, Papilionoideae) no Estado do Rio de Janeiro. Rodriguésia 58: 469-483.

Mattos, N.F. 1979a. O gênero Andira Lam. (LeguminosaePapilionoideae) no Brasil. Acta Amazonica 9: 241-266.

Mattos, N.F. 1979b. O gênero Hymenolobium Benth. (Leguminosae) no Brasil. Roessléria 3: 13-53.

Meira-Neto, J.A.A. \& Martins, F.R. 2002. Composição florística de uma floresta estacional semidecidual montana no município de Viçosa-MG. Revista Árvore 26: 437-446.
Mendonça Filho, C.V., Forni-Martins, E.R. \& Tozzi, A.M.G.A. 2002. New chromosome counts in Neotropical Machaerium Pers. Species (Fabaceae) and their taxonomic significance. Caryologia 55: 111-114.

Myers, N., Mittermeier, R.A., Mittermeier, C.G., Fonseca, G.A.B. \& Kent, J. 2000. Biodiversity hotspots for conservation priorities. Nature 403: 853-858.

Oliveira Filho, A.T. 2006. Catálogo das árvores nativas de Minas Gerais: mapeamento e inventário da flora nativa e dos reflorestamentos de Minas Gerais. Universidade Federal de Lavras.

Pennington, R.T. 2003. Monograph of Andira (Leguminosae-Papilionoideae). Systematic Botany Monographs 64: 1-143.

Pennington, T.D. 1997. The genus Inga: Botany. Royal Botanic Gardens, Kew.

Polhill, R.M. 1981. Papilionoideae. In: R.M. Polhill \& P.H. Raven (eds.). Advances in Legume Systematics part I. Royal Botanic Gardens, Kew, pp.191-208.

Radford, A.E., Dickison, W.C., Massey, J.R. \& Bell, C.R. 1974. Vascular plant systematics. Harper \& Row, New York.

Rodrigues, I.M.C. \& Garcia, F.C.P. 2007. Papilionoideae (Leguminosae) arbóreas e lianas na Estação de Pesquisa, Treinamento e Educação Ambiental (EPTEA), Mata do Paraíso, Viçosa, Zona da Mata Mineira. Revista Árvore 31:521-532.

Rudd, V.E. 1977. The genus Machaerium (Leguminosae) in Mexico. Boletin de la Sociedad Botanica de México 37: 119-146.

Saporetti Júnior, A.W. 2005. Composição florística e estrutural do componente arbóreo em um remanescente de Floresta Atlântica Montana, Araponga, MG. Dissertação de Mestrado, Universidade Federal de Viçosa, Viçosa.

Sartori, A.L.B. \& Tozzi, A.M.G.A. 1998. As espécies de Machaerium Pers. (Leguminosae - Papilionoideae Dalbergieae) ocorrentes no estado de São Paulo. Revista Brasileira de Botânica 21: 211-246.

Soares, M.P., Saporetti Junior, A.W., Meira Neto, J.A.A., Silva,A.F. \& Souza, A.L. 2006. Composição florística do estrato arbóreo de Floresta Atlântica interiorana em Araponga - Minas Gerais. Revista Árvore 30: 859-870.

Tamashiro, J.Y. 1989. “Estudos taxonômicos e morfológicos do gênero Piptadenia sensu Bentham no sudeste do Brasil. Avaliação das modificações taxonômicas recentemente propostas”. Dissertação de Mestrado, Universidade Estadual de Campinas, Campinas.

Veloso, H.P., Rangel Filho, A.L.R. \& Lima, J.C.A. 1991. Classificação da vegetação brasileira, adaptada a um sistema universal. IBGE, Departamento de Recursos Naturais e Estudos Ambientais, Rio de Janeiro.

Wojciechowski, M.F., Lavin, M. \& Sanderson, M.J. 2004. A phylogeny of legumes (Leguminosae) based on analysis of the plastid matK gene resolves many well-supported subclades within the family. American Journal of Botany 91: 1846-1862. 